\author{
UNIVERSIDADE DE BRASÍLIA \\ EDUCAÇÃO E PROMOÇÃO DE SAÚDE
}

Sandra Saraiva Leão Leite da Silva

\title{
Promoção da Saúde e Terapia Comunitária \\ Um Diálogo que Promove a Participação Social
}


Sandra Saraiva Leão Leite da Silva

\section{Promoção da Saúde e Terapia Comunitária Um Diálogo que Promove a Participação Social}

Ensaio apresentado ao IV Curso de Especialização em Educação e Promoção da Saúde como exigência parcial para obtenção do título de especialista.

Orientador: Professor Dr. Elioenai Dornelles Alves.

\section{BRASÍLIA/DF}




\section{RESUMO}

Entendemos saúde como processo dinâmico que abrange múltiplas configurações, envolvendo aspectos sócio-históricos, culturais, emocionais, econômicos, políticos e pessoais, entre outros. Conseqüentemente, pensar em saúde é entender que a falência do modelo biomédico e as profundas transformações sociais ocorridas nas últimas décadas, trouxeram uma noção de sujeito diferenciada. Assim, pensando nesse sujeito singular, complexo e dinâmico e pensando em ações que funcionem como fomentadoras da saúde, decidimos realizar um trabalho que tivesse como objetivo fazer uma reflexão que compreendesse as práticas da Terapia Comunitária como ferramentas de Promoção da Saúde. Para tanto, o trabalho buscou conhecer os princípios norteadores de práticas educativas e promotoras de saúde que norteiam a formação do Terapeuta Comunitário, com ênfase na pedagogia libertadora de Paulo Freire. Desta forma analisamos como a Terapia Comunitária estimula a participação social nos espaços democráticos onde se estabelece. Sendo a saúde processo dinâmico e abrangente, que alia valores como vida, solidariedade, democracia, cidadania, participação e outros, compreendemos, claramente, o quanto a prática da Terapia Comunitária se enraíza na edificação e aprimoramento da Promoção da Saúde. A metodologia utilizada foi a revisão bibliográfica onde procuramos compreender a noção de Saúde fundamentadas nas principais Conferências Internacionais de Saúde e a análise de conceitos como participação social/controle social, empowerment e educação permanente; bem como a compreensão da Terapia Comunitária a partir dos seus pilares teóricos: pensamento sistêmico, teoria da comunicação, antropologia cultura, resiliência e pedagogia de Paulo Freire. Abalizado nos estudos realizados, compreendemos o valor da Terapia Comunitária como construtora da Promoção da Saúde, uma vez que se trata de instrumento capaz de construir redes sociais solidárias, de fortalecimento das competências dos atores sociais e do despertar destes sujeitos para o seu papel transformador.

Palavras-chave: promoção da saúde, terapia comunitária, participação social, atores sociais. 


\begin{abstract}
We understand health as a dynamic process that includes multiple settings, involving socio-historical, cultural, emotional, economic, political and personal, among others. Therefore, think about health is to understand that the failure of the biomedical model and the profound social changes in recent decades have brought a different notion of the subject. So, thinking that an individual in complex and dynamic thinking and actions that work as fueling health, we decided to do a job that has as objective to discuss who understands the practice of therapy as tools for Community Health Promotion For this, study aimed at guiding principles of educational practice and health promoters that guide the formation of the Community Practitioner, with emphasis on liberating pedagogy of Paulo Freire. Thus we analyze how the Community Therapy encourages social participation in democratic spaces where he settled. As the health and comprehensive dynamic process that combines values of life, solidarity, democracy, citizenship, participation, and others, understand clearly how the practice of Community Therapy is rooted in the construction and improvement of the Promotion of Health The methodology used was the literature which seek to understand the concept of health based on the main International Conferences on Health and the analysis of concepts such as social participation / control, empowerment, and education; an understanding of Community Care from its theoretical pillars: systems thinking, communication theory, anthropology, culture, resilience and pedagogy of Paulo Freire. Authoritative studies undertaken, we understand the value of Community Therapy as a builder of Health Promotion, since it is an instrument capable of building social networks of solidarity, to strengthen the powers of social actors and the awakening of these subjects to their changing role.
\end{abstract}

Keywords: health promotion, community therapy, social participation, social actors. 


\section{SUMÁRIO}

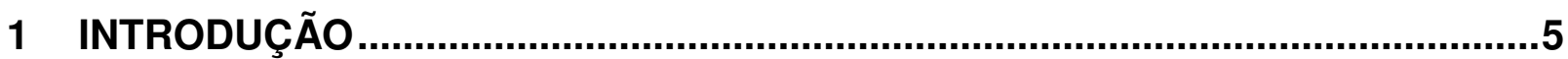

2 REVISÃO TEÓRICA DA PROMOÇÃO DA SAÚDE..........................................10

2.1 BREVE REFLEXÃO SOBRE AS PRINCIPAIS CONFERÊNCIAS EM PROMOÇÃO

DE SAÚDE.

2.1.1 I Conferência Internacional sobre Promoção da Saúde - Ottawa .10

2.1.2 I Conferência Internacional em Cuidados Primários de Saúde - Alma-Ata.13

2.1.3 II Conferência Internacional sobre Promoção de Saúde - Adelaide .14

2.1.4 III Conferência Internacional sobre Promoção de Saúde - Sundswal ..........15

2.1.5 IV Conferência Internacional sobre Promoção de Saúde - Jacarta ..............15

2.1.6 Conferência Internacional da Colômbia...........................................................16

3 PROMOÇÃO DA SAÚDE - CAMINHOS PARA CONSTRUI-LA ..........................18

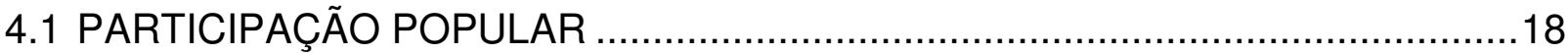

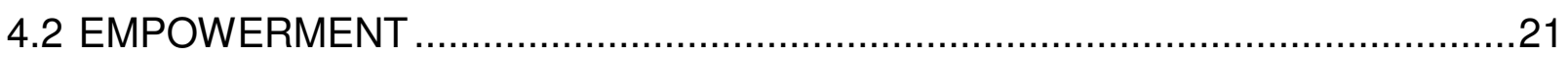

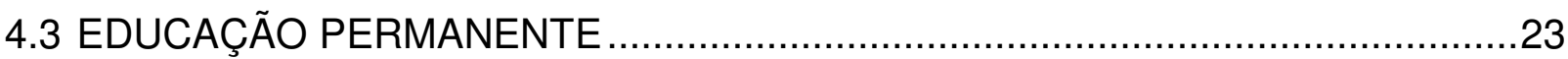

4 TERAPIA COMUNITÁRIA

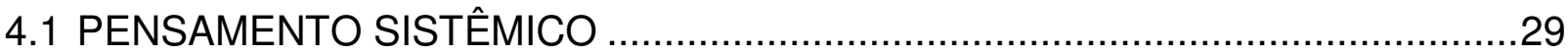

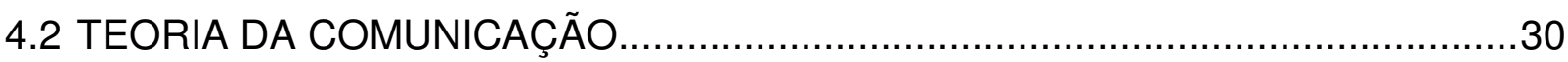

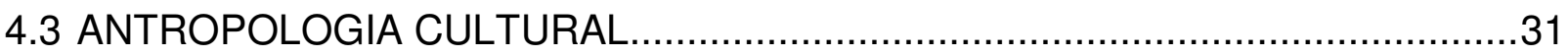

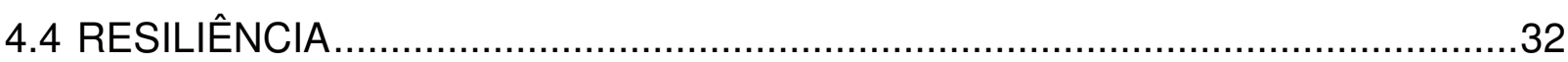

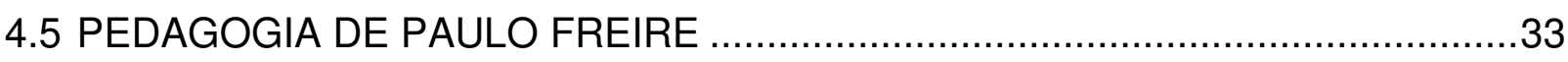

5 A TERAPIA COMUNITÁRIA PROMOVENDO A SAÚDE - UM EXEMPLO .........37

6 VIVÊNCIA - ENTENDENDO A RODA DE TERAPIA COMUNITÁRIA ................40

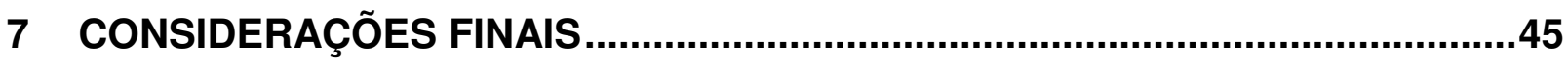

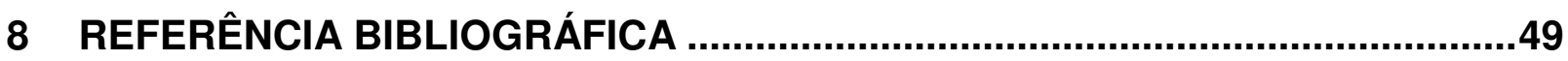




\section{INTRODUÇÃO}

O esgotamento do modelo biomédico, as profundas transformações sociais ocorridas nas últimas décadas, as teorias pós-modernas que trazem em seu bojo uma noção de sujeito diferenciada, isso tudo facilitou o surgimento e fortalecimento do movimento da Promoção da Saúde. Este movimento teve seu momento inicial em Alma-Ata, URSS, mas foi em Ottawa, no Canadá, que se consolidou como um marco importante e revolucionário de se pensar saúde, afastando-se definitivamente de uma visão míope de saúde como ausência de doença.

A Promoção da Saúde está relacionada a questões sociais, econômicas, biológicas, culturais, ecológicas e outras. Podemos dizer também que a Promoção da Saúde é um saber cuidar: de si mesmo, do outro, do meio ambiente. Cuidar é antes de mais nada uma atitude. Assim, é maior que um instante de atenção ou zelo; é um continuum de ocupação, responsabilização e preocupação com o outro (BOFF, 1999).

Desde o início do século XX, encontram-se estudos que admitem ser a doença, qualquer que seja ela, uma realidade construída que está intrinsecamente relacionada com as características de cada sociedade, esses estudos são de base sociológica e antropológica. Antes desses estudos o que havia era tão somente o pensamento orientado a partir de uma visão positivista que não compreendia os condicionantes sócio-histórico-culturais. Responsabilizar o indivíduo pela própria doença, desconsiderando as causas sócio-históricas é um pensamento típico de modelos que desconhecem a importância do cultural e do histórico que estão presentes no processo saúde-doença; entretanto esse modelo vem se enfraquecendo e deste modo o que se percebe é o surgimento de um novo paradigma que enfatiza a relação "coletivo-individual" como uma relação dialética, na qual a individualidade não pode ser pensada sem sua contrapartida no social (KOWALSKI, 2002).

Sendo a Promoção da Saúde a soma de uma série de premissas como: alimentação equilibrada/balanceada, estilo de vida, oportunidade de estudo, empregabilidade (opção de trabalho/emprego para todos) e equidade, entre outros, ela tem como propósito buscar alcançar um nível de saúde adequado para o 
sujeito de maneira que ele, com saúde, seja capaz de ter uma vida produtiva do ponto de vista social e econômico.

Para tanto é preciso enfrentar o desafio de construir uma sociedade com justiça social e equidade, condição 'sine qua non' para se alcançar a saúde. É preciso também coragem para afastar-se da visão reducionista enraizada no modelo positivista de homem e ir ao encontro de uma visão de sujeito sóciohistórico-cultural.

Tal conceito então está bem distante do modelo biomédico, muito difundido ainda, que prioriza a medicalização e privilegia as compreensões dos determinantes biológicos, perspectiva esta onde o sujeito é subtraído do seu contexto sóciohistórico-cultural e passa a ser avaliado enquanto indivíduo puramente biológico. $\mathrm{E}$ aqui lembramos as contribuições de Vygotsky que, em seus estudos, já rejeitava essa visão de homem genuinamente biológico, desvinculado das dimensões culturais, sociais e históricas. Para ele a produção do conhecimento surge no momento que o sujeito interage com seu meio e vai se apropriando da cultura e dos saberes.

(...) a concepção vigotskiana enfatiza o desenvolvimento do indivíduo na interação social; especificamente, o individual é formado pela interiorização de atividades que têm lugar no meio social e pela interação que ocorre na zona de desenvolvimento proximal. A cognição é um produto social alcançado por intermédio da interação (ROSA; MONTERO, 1996, P. 78).

A Promoção da Saúde (PS) é um movimento abrangente, com enfoque técnico e político que entende a saúde como um processo que alia valores como: "vida, saúde, solidariedade, equidade, democracia, cidadania, desenvolvimento, participação" (BUSS, 2000, p. 165). Diante dessa nova visão de mundo e de sujeito, e conseqüentemente de uma nova visão de saúde, muito ainda deve ser feito do ponto de vista dos sistemas de cuidados à saúde, tão ultrapassados e incongruentes, inclusive pela dificuldade encontrada em instituir um pensamento complexo sobre a mesma.

Considerando que a construção e efetivação da PS é processo que se dará no encontro estabelecido entre os diversos atores sociais e considerando também essa noção de sujeito compreendido a partir das múltiplas dimensões - culturais, sociais, históricas - pensamos num estudo que pudesse promover um diálogo entre a Terapia Comunitária e Promoção da Saúde. Sendo a Terapia Comunitária um espaço de interlocução entre diversos atores sociais, acreditamos que ela é uma 
excelente ferramenta da Promoção da Saúde. Ambos os movimentos: Terapia Comunitária e Promoção da Saúde, buscam romper com um pensamento linear de causa e efeito das doenças de um modo geral, e conseqüentemente de tratamento das mesmas. Deste modo, é possível pensar em formas diferentes das utilizadas na medicina tradicional, formas que muitas vezes são até mais eficazes, uma vez que são desenvolvidas/pensadas a partir do diálogo com o próprio sujeito. (SEGRE; FERRAZ, 1997).

No ano de 1987 surge em Fortaleza, capital do estado do Ceará, um movimento alternativo em saúde cujo objetivo era ajudar sujeitos em sofrimento psíquico, moradores da favela do Pirambu, uma das maiores da cidade. Segundo Barreto (2008), esses sujeitos eram atendidos através do Projeto de Apoio aos Direitos Humanos daquela comunidade. $\mathrm{O}$ advogado que coordenava o projeto era 0 Dr. Airton Barreto que, com pouco tempo de trabalho, percebeu que as queixas relacionadas às questões jurídicas era apenas a ponta do 'iceberg', posto que era resultado de problemas sociais, psicológicos, emocionais, tão comuns em comunidades como aquela, de um povo sofrido, esquecido e silenciado. Foi então que o Dr. Airton Barreto convidou, para ajudá-lo a ajudar aquela comunidade, seu irmão, o Dr. Adalberto de Paula Barreto, então professor da disciplina de Medicina Social da Faculdade de Medicina da Universidade Federal do Estado do Ceará. Doutor em psiquiatria, Adalberto Barreto, movido pelo sentimento de compaixão pelo sofrimento daquele povo, aceitou o desafio de atender os sujeitos encaminhados por seu irmão. Como o número de atendimento crescia constantemente, ficou resolvido que o professor e seus alunos não mais atenderiam aqueles 'pacientes' no Hospital Universitário, mas sim na própria comunidade. Logo, o atendimento que antes era individual, transformou-se.

Inicialmente, recebia, no Hospital Universitário, pacientes vítimas de conflitos de abandono e miséria humana, que os levavam a ter episódios de depressão e crises psicóticas, em que era evidente a questão da perda da identidade. Eles eram enviados por meu irmão, Airton Barreto, advogado e coordenador do Centro de Direitos Humanos do Pirambu, também sensibilizado pela situação de abandono de pessoas que ainda não ascenderam aos direitos ligados à cidadania. Diante daquela demanda progressiva, um dia, decidi, com meus alunos do curso de psiquiatria, deixar o conforto e a segurança do consultório do Hospital Universitário para ver as pessoas em seu próprio contexto (BARRETO, 2008, p. 23). 
Foi então nesse espaço aparentemente inóspito, de carências não só materiais, mas de exclusão e abandono, que nasceu o embrião do que hoje é a Terapia Comunitária. Espaço democrático e de Promoção da Saúde, foi construída e alicerçada nos seguintes pilares teóricos: Pensamento Sistêmico, Teoria da Comunicação, Antropologia Cultura, Pedagogia de Paulo Freire e Resiliência ${ }^{1}$.

$\mathrm{Na}$ Terapia Comunitária, os sujeitos se encontram e trocam suas experiências (dores, alegrias, medos, habilidades e saberes). Nessa troca, uns aprendem com os outros; na Terapia Comunitária (TC), existe o que Paulo Freire chamava de educação significativa, pois ninguém ensina ninguém, mas vão aprendendo no encontro que se estabelece. Nesses encontros vão surgindo idéias novas, possibilidades de enfrentamento diante do sofrimento e/ou carências.

Uma comunidade que se encontra para trocar experiências, valorizar os saberes, está preparada para assumir seu papel transformador. Fazendo uma analogia entre Promoção da Saúde e Terapia Comunitária, é fácil identificar diversas afinidades/semelhanças, ou seja, pontos de confluências capazes de mostrar o quanto uma está relacionada à outra. Algumas dessas semelhanças são: Educação Permanente em Saúde, Empowermet ${ }^{2}$ e de Participação Social, conceitos estes que serão abordados oportunamente.

A Terapia Comunitária é então um instrumento capaz de construir redes sociais solidárias, de fortalecimento das competências dos atores sociais e do despertar desses sujeitos para seu papel transformador. Nesse sentido acredita-se que a TC é uma excelente ferramenta de auxílio na Promoção da Saúde.

Assim, o objetivo desse trabalho é de, a partir de uma revisão bibliográfica dos movimentos - Promoção da Saúde e Terapia Comunitária - fazer uma análise da contribuição que a TC pode dar para a construção da Promoção da Saúde.

Em acréscimo, este trabalho está assim organizado: Capítulo I, uma visão geral onde é abordado o tema da Promoção da Saúde e da Terapia Comunitária, sua importância e os objetivos e justificativas que nos levaram a pensar nesse tema. Capítulo II, encontra-se uma revisão teórica da Promoção da Saúde - as principais cartas de saúde, com seus pressupostos e contribuições. Capítulo III, uma discussão sobre como se construir a Promoção da Saúde - com análise de conceitos como: Participação Social (controle social), Empowerment e Educação

\footnotetext{
${ }^{1}$ Nota da Autora: Capacidade de Superação/enfrentamento diante de situações adversas.

${ }^{2}$ Nota da Autora: Diz respeito a 'auto-poder'; autonomia pessoal - um poder sobre si mesmo.
} 
Permanente. Cabe ressaltar que a valorização destes conceitos não se deu de forma aleatória, senão porque são conceitos que estão direta e intrinsecamente ligados à Terapia Comunitária. Capítulo IV, o papel da Terapia Comunitária na construção de redes solidárias e controle social, entendidas a partir dos seus pilares teóricos, que são: Pensamento Sistêmico, Teoria da Comunicação, Antropologia Cultural, Pedagogia de Paulo Freire e Resiliência, com ênfase na Pedagogia de Paulo Freire, uma vez que esta pedagogia é também base da compreensão da Promoção da Saúde. Capítulo V, como modelo de ação fomentadora de Promoção da Saúde, encontra-se o exemplo da Paranoarte, projeto social que nasceu a partir das experiências trocadas numa Roda de TC. Trata-se de capítulo valoroso, posto que este trabalho tem como finalidade identificar o grau de relação existente entre os dois movimentos: Terapia Comunitária e Promoção da Saúde e analisar se a TC é de fato promotora de saúde, se opera como instrumento capaz de fomentar ações que promovem cidadania, inclusão social, autonomia, entre outros questionamentos. Capítulo VI, traz a 'vivência' da Roda de TC, mostra o passo-a-passo dos encontros. Capítulo VII, encontram-se as reflexões e considerações finais sobre o trabalho realizado e por último, o Capítulo VIII, com o Referencial Bibliográfico utilizado para a pesquisa deste Trabalho de Conclusão de Curso. 


\section{REVISÃo TEÓRICA DA PROMOÇÃO DA SAÚDE}

A revisão teórica da Promoção da Saúde está fundamentada nas principais Conferências Internacionais de Saúde, na seguinte ordem: I Conferência Internacional sobre Promoção da Saúde - Ottawa; I Conferência Internacional em Cuidados Primários de Saúde - Alma-Ata; II Conferência Internacional sobre Promoção da Saúde - Adelaide; III Conferência Internacional sobre Promoção da Saúde - Sundswal; IV Conferência Internacional sobre Promoção da Saúde Jacarta e V Conferência Internacional sobre Promoção da Saúde -Colômbia.

\subsection{BREVE REFLEXÃO SOBRE AS PRINCIPAIS CONFERÊNCIAS EM PROMOÇÃO DE SAÚDE}

Resolvemos fazer uma breve reflexão teórica sobre as mais importantes conferências em promoção de saúde acontecidas até hoje, com o objetivo de compreender como este assunto vem evoluindo ao longo dos anos.

\subsubsection{Conferência Internacional sobre Promoção da Saúde - Ottawa}

A primeira Conferência Internacional sobre Promoção da Saúde foi realizada em Ottawa, no Canadá, em 1986. Veio depois de 8 (oito) anos da I Conferência Internacional sobre Cuidados Primários de Saúde, realizada em 1978 em Alma-Ata. Logo mais faremos uma breve explanação sobre a importância da Declaração de Alma-Ata, esta que foi realmente a responsável por ter colocado um novo olhar para o campo da saúde, colocando como meta a "saúde para todos no ano 2000" (BUSS, 2000, p. 170).

Segundo Buss (2000), os simpatizantes da estratégia para a Promoção da Saúde saíram da Conferência de Alma-Ata tão animados, que dali surgiu a força para, oito anos depois, ser realizada a I Conferência Internacional sobre PS, nascendo então o documento mais importante sobre Promoção de Saúde: a Carta de Ottawa. Mas além da Conferência de Alma-Ata, ela também teve sua origem nos documentos da Organização Mundial de Saúde sobre "os objetivos da saúde para todos", além do debate ocorrido anteriormente na Assembléia Mundial de Saúde que colocava em pauta a questão da intersetorialidade. 
Sendo a Carta de Ottawa o documento de referência no desenvolvimento das idéias de PS, traz consigo o reforço de idéias inovadoras como a inclusão da comunidade dentro de um processo de capacitação para que esta possa atuar na busca de soluções e na busca de uma melhor qualidade de vida e saúde, além de mostrar os determinantes múltiplos da saúde; outro ponto muito importante reforçado pela Carta de Ottawa é a questão da intersetorialidade, uma vez que entende que saúde 'transcende' a noção de ausência de doença. Nas palavras de Buss (2000):

A Carta de Ottawa define PS como o processo de capacitação da comunidade para atuar na melhoria da sua qualidade de vida e saúde, incluindo uma maior participação no controle deste processo [...] 0 documento aponta para os determinantes múltiplos da saúde e para a 'intersetorialidade', ao afirmar que dado que o conceito de saúde como bemestar transcende a idéia de formas sadias de vida, a PS transcende o setor saúde. E completa, afirmando que as condições e requisitos para a saúde são: paz, educação, habitação, alimentação, renda, ecossistema estável, recursos sustentáveis, justiça social e eqüidade. Defesa da saúde, capacitação e mediação são, segundo a Carta de Ottawa, as três estratégias fundamentais da Promoção da Saúde (BUSS, 2000, p. 170).

Assim, a Carta de Ottawa traz a idéia de Promoção da Saúde como uma maneira de alcançar "um estado adequado de bem-estar físico, mental e social" e contempla nos pré-requisitos para a saúde, outras dimensões, uma vez que coloca como condição para se alcançar a saúde: o cuidado/atenção com aspectos relacionados à paz, educação, alimentação, renda, equidade, entre outros. Todas essas idéias, oriundas da Carta de Ottawa, foram primordiais para dar abertura a um grande movimento que se desdobrou em outras Conferências (TEIXEIRA, 2004)

A Promoção da Saúde dar-se-á a partir de um olhar múltiplo e transversal, tanto na prática quanto nos conceitos. É capacitar a comunidade - o sujeito, para que este possa ter controle sobre os determinantes de saúde, todavia isso será possível se for dado a esse sujeito oportunidades de conhecimento (educação), que - levará a buscar novas possibilidades, novos caminhos, sendo possível fazer escolhas mais saudáveis. Ser co-participante na construção de ambientes favoráveis à saúde (Canadá, 1986). Em acréscimo vale ressaltar a importância da participação de todos os atores sociais envolvidos nas demandas, como bem coloca o texto:

(...) a promoção da saúde exige a ação coordenada de todos os implicados: os governos, os setores sanitários e outros setores sociais e econômicos, as organizações beneficentes, as autoridades locais, a indústria e os meios de comunicação. As 
pessoas de todos os meios sociais estão implicadas tanto com os indivíduos quanto com as famílias e comunidades. Aos grupos sociais e profissionais e ao pessoal do grupo sanitário corresponde, especialmente, assumir a responsabilidade de atuar como mediadores entre os interesses antagônicos e a favor da saúde (MARCONDES, 2004, p. 7).

A Carta de Ottawa lista as condições necessárias, bem como os recursos que deverão ser envolvidos para o cumprimento da meta 'saúde para todos no ano 2000'. Consegue identificar alguns campos de ações: políticas públicas saudáveis, lembrando que essas políticas terão impactos diretos na melhora ou piora da saúde da população; criação de ambientes favoráveis à saúde: reconhece que nossas sociedades são complexas, o que requer um diálogo entre os diferentes setores; o poder político das comunidades que nada mais é do que o fortalecimento da comunidade através da sua valorização que virá com a educação (BUSS, 2003).

De fato a PS efetivar-se-á com a participação da comunidade, quando esta reconhecer suas possibilidades. É a comunidade que, articulada e participativa, dirá quais suas prioridades; isso é promover o reforço da ação comunitária. Quando o desenvolvimento social e pessoal for promovido, a comunidade estará mais preparada para exercitar o controle sobre si mesma, sobre os determinantes de sua saúde e também melhor preparada para fiscalizar e cooperar na realização de políticas públicas de saúde. Esse movimento de fato é sistêmico, pois que se retroalimenta: a PS promove o poder e o saber articulado das comunidades, e estas, 'empoderadas ${ }^{3}$, promovem a PS. Para a construção de uma melhor qualidade de vida, é necessária uma visão exata dos determinantes múltiplos de saúde; ora, se os determinantes da saúde são vários, a PS deve transcender os espaços do setor de saúde.

Assim, é necessário que todos se responsabilizem pela saúde: os profissionais de saúde, os governos, a comunidade, as organizações não governamentais, os serviços sanitários etc, o que está relacionado à reorientação dos serviços de saúde e parcerias intersetoriais (BUSS, 2003). Sendo a saúde o resultado direto da vida cotidiana, ela depende do compromisso de cada um em manter ambientes que sejam de fato favoráveis à saúde, seja nas escolas, nas

\footnotetext{
${ }^{3}$ Nota da Autora: de acordo com o dicionário Michaelis 1998, esse termo vem de apoderar (meter-se na posse de, senhorear-se). Aqui, entretanto, deve ser entendido como 'aquele que tem autonomia; poder sobre si mesmo; consciência crítica'.
} 
instituições, em casa, no lazer. É participar, educar-se constantemente, é tomar atitude em favor de si, mas também em favor do outro. Esse cuidado amplo envolve a saúde física, mental, social, espiritual e ecológica, esse cuidado diz respeito à criação de ambientes favoráveis à saúde.

\subsubsection{Conferência Internacional em Cuidados Primários de Saúde - Alma-Ata}

A I Conferência Internacional em Cuidados Primários de Saúde ${ }^{4}$ aconteceu em Alma-Ata, antiga URSS, no ano de 1978 e teve importância ímpar em todo o processo de construção da PS, desde o início até os dias de hoje. Trouxe pontos fundamentais de reflexão como: "a saúde como direito humano fundamental" (Buss, 2000, p. 170). Esta conferência estava presa a uma visão de saúde linear, influenciada que estava pela própria OMS, pois que trazida a saúde como estado de completo bem-estar físico, mental e social. Isso, todavia, não tira da Declaração toda sua importância, uma vez que há 31 anos foi precursora de toda a construção percebida hoje, em 2009.

Trouxe, por exemplo, questionamentos contundentes sobre a perversa desigualdade sócio-cultural entre os povos, proveniente de igual perversa distribuição de renda e enfatizou a necessidade de escuta dos povos, como sujeitos ativos no processo de saúde. Como se percebe, todas as idéias muito inovadoras para a época e todas essas reflexões tinham como objetivo último a meta saúde para todos no ano 2000.

Comparando a Carta de Ottawa e a Declaração de Alma-Ata, é fácil compreender a crítica feita por David Tejada de Rivero, no artigo Alma-Ata: 25 años después. No texto, o autor faz uma crítica à valorização de uns em detrimento de outros (povos/países), em relação a todos os momentos de discussões realizadas mundo a fora sobre Promoção de Saúde. Para Rivero, a despeito das incomparáveis contribuições de Alma-Ata, percebe-se uma falha: segundo o autor, a grande pena é que o "saúde para todos" tenha sido passado de forma errônea, simplista, o que leva a imaginar uma forma de programa muito mais

\footnotetext{
${ }^{4}$ Optamos por fazer uma reflexão mais detalhada sobre a Conferência Internacional em Cuidados Primários de Saúde, uma vez que acreditamos que esta Conferência foi o pontapé inicial e mais importante que ocorreu sobre Promoção de Saúde. Assim, por entendermos que não tem sido dada à Declaração de Alma-Ata todo o valor que ela merece, resolvemos prestar essa homenagem àqueles que, pioneiramente, pensaram em fazer a Promoção da Saúde. Utilizamos como base para nossa reflexão crítica o texto do David Tejada de Rivero, no artigo Alma-Ata: 25 años después.
} 
técnico e burocrático do que social e político como de fato foi a proposta (RIVERO, 2003).

Muitas foram as contribuições de Alma-Ata, semelhantes às de Ottawa, entretanto aquela tem sido negligenciada em função desta, o que pode ter ocorrido inclusive por questões políticas; é de certa forma esperado que o 'mundo capitalista' tenha usurpado do mundo 'socialista' as contribuições fantásticas que este último trouxe para a saúde.

A simples questão da tradução de termos como: cuidado, atenção e primária, observada por Rivero, pode ser um indicativo da manipulação não-casual da contribuição de Alma-Ata. Idéias como: Cuidado Integral de Saúde para Todos e por Todos, visão de saúde multisetorial e multidisciplinada, visão promocional e preventiva de saúde, que também deve ser participativa e descentralizada e participação direta, ativa e efetiva das pessoas, definitivamente não combina com uma interpretação que traz a idéia de Atenção Reparativa das Doenças e Baixo Custo para População mais Pobre (RIVERO, 2003).

Rivera faz uma crítica inclusive em relação à tradução dos termos 'primário' e 'cuidado'. Segundo ele, a interpretação de 'cuidado' correta, ou seja, em consonância com a idéia de Alma-Ata, seria: "El cuidado denota relaciones horizontales, simétricas y participativas" (RIVERO, 2003, p. 2). Já o termo primário, parece ter sido interpretado como sinônimo de 'atrasado', sendo que a idéia correta seria mais voltada para uma questão de "ordem de importância".

Detive-me um pouco mais nas reflexões sobre os aportes da I Conferência Internacional sobre Cuidados Primários de Saúde, realizada em Alma-Ata, muito mais no sentido de fazer uma referência justa a uma contribuição tão importante e que, ao longo dos anos, vem sendo esquecida e mesmo negligenciada.

\subsubsection{Conferência Internacional sobre Promoção de Saúde - Adelaide}

A Segunda Conferência Internacional de Saúde foi na Austrália, conhecida como Declaração de Adelaide, foi realizada em 1988. Esta conferência ressaltou o valor das políticas públicas como condição para a criação de vidas saudáveis e identificou quatro campos indispensáveis para a promoção da saúde, a saber: "apoio à saúde da mulher, alimentação e nutrição; tabaco e álcool e a criação de ambientes 
saudáveis" (OLINDA, 2007 p. 65), além do desenvolvimento de novas alianças na saúde e compromissos para uma saúde pública global.

\subsubsection{Conferência Internacional sobre Promoção de Saúde - Sundswal}

Já a Terceira Conferência Internacional sobre Promoção da Saúde, ocorreu na Suécia em 1991. Conhecida como Conferência de Sundswal, trouxe como tema central: ambientes favoráveis à saúde. Um dos aspectos para a construção de um ambiente favorável, segundo a Carta de Sundsvall, seria o compromisso "com os direitos humanos, com a paz e com realocação de recursos oriundos da corrida armamentista" 5 . A Carta analisa a condição de pobreza e privação ocorridas em ambientes desprovidos de saúde.

\subsubsection{Conferência Internacional sobre Promoção de Saúde - Jacarta}

Considerada a Quarta Conferência Internacional de Promoção da Saúde, a Declaração de Jacarta, ocorreu em 1997 na Indonésia. Nesta Conferência, ficou enfatizado "a paz, o abrigo, a instrução, a segurança social, as relações sociais, o alimento, a renda, o direito de voz das mulheres, um ecossistema estável, o uso sustentável dos recursos, justiça social, respeito aos direitos humanos e equidade como os elementos necessários e indispensáveis para a saúde" (OLINDA, 2007 p. 66).

Em cada Conferência, um novo 'tópico' vem se inserir, o que é esperado, uma vez que num mundo globalizado e dinâmico, as necessidades se modificam. Em Jacarta houve como preocupação ainda, a inclusão do Setor Privado nas discussões em relação à Promoção da Saúde. A eliminação das barreiras colocadas entre os diversos setores da sociedade, bem como das organizações, sejam elas governamentais ou não-governamentais, é condição essencial para o despertar da cooperação, da parceria, do compromisso e da co-responsabilização de todos para todos. Sem dúvida que já passava da hora de se incluir o setor privado nas discussões, buscando inseri-lo como co-responsável na Promoção da Saúde. É

\footnotetext{
5 Disponível em: <http://portal.saude.gov.br/portal/arquivos/pdf/declaracoesecarta portugues.pdf> acesso em 08 de agosto de 2009.
} 
responsabilidade do setor privado, investir em projetos sociais que busquem promover a saúde e qualidade de vida da população.

\subsubsection{Conferência Internacional da Colômbia}

Entre uma Conferência Internacional e outra, muitos encontros ocorreram mundo a fora. Em 1992 foi realizada a V Conferência Internacional de Promoção da Saúde, em Santa Fé de Bogotá, na Colômbia, contando com a participação de 21 países, dentre os quais o Brasil. Essa declaração foi intitulada "Promoção e Igualdade", tema pertinente considerando que grande parte das dificuldades encontradas para a melhoria da saúde, em vários países da América Latina, está associada à péssima distribuição de renda, agravada pelas crises políticas e econômicas. O documento traz 5 premissas: superação das desigualdades; reafirmação da democracia; equidade; desenvolvimento integral e organização das ações sanitárias. E como estratégia para se conseguir a PS: estimular a cultura da saúde; modificar/otimizar o setor saúde e estímulo para um compromisso social que pense em saúde como prioridade (OPAS, 1992).

Os países participantes concordaram e se comprometeram em assumir estratégias que tivessem como ponto principal o respeito e direito à vida e à paz, considerados importantes para a promoção da saúde. Assim, o documento define 11 (onze) estratégias como condição 'sine qua non' para a conquista da Promoção da Saúde na América Latina, entre elas estão: estimular uma compreensão de saúde ampla, que envolve fatores políticos, econômicos, sociais, culturais e ambientais; promover a integração social para buscar a PS; estimular políticas públicas para a criação de ambientes favoráveis à saúde; estabelecer políticas que visem reduzir gastos desnecessários como os militares e os provenientes de guerras; empoderamento/participação social e outros. (OPAS, 1992).

Cabe aqui uma breve digressão com o objetivo de criticar a ausência de representantes de outros setores que não o da saúde. Depois de tantos Congressos e Conferências, é de se espantar o fato de não terem ido a Bogotá, Ministros e/ou Secretários de Fazenda, Educação, Ciência e Tecnologia, enfim, representantes de vários setores. Se a idéia era: "conciliando os interesses econômicos e os propósitos sociais de bem-estar para todos, assim como trabalhar pela solidariedade e equidade social, condições indispensáveis para a saúde e o 
desenvolvimento" (OPAS, 1992, p. 1), é inexplicável a ausência de outros setores tão importantes para a efetivação da intersetorialidade, tão discutida em todas as Conferências anteriores.

Buscamos fazer um levantamento reflexivo das principais Conferências Internacionais de Saúde com a idéia de construir uma linha de raciocínio que ajude a entender como vem se construindo, ao longo dos anos, a idéia de Promoção de Saúde. Outrossim, pela importância que todas elas têm nos diversos movimentos sanitaristas implementados no Brasil, e conseqüentemente na construção de políticas públicas realizadas nos últimos tempos. 


\section{PROMOÇÃO DA SAÚDE - CAMINHOS PARA CONSTRUI-LA}

A Promoção da Saúde é tema recorrente em vários espaços: sociais, culturais, educacionais e políticos, entre outros. No que diz respeito à produção de conhecimento também percebemos sua influência e o interesse no tema, onde um primoroso exemplo é este curso de especialização oferecido pelo Núcleo de Estudos em Educação e Promoção da Saúde - NESPROM. Este Núcleo foi criado na década de 90 quando houve uma parceria com a Universidade de Granada (Espanha) para realização de um seminário sobre Promoção da Saúde, apoiado pelo DEX/UNB. Este ano (2009) o NESPROM comemora 17 anos de trabalho e pesquisa na área da Promoção da Saúde, momento brindado com a realização o IV Curso de Especialização em Educação e Promoção da Saúde ${ }^{6}$.

Desta forma, diversos são os caminhos que levam à Promoção da Saúde. Para este trabalho, faremos um levantamento dos principais eixos teóricos utilizados na PS, quais sejam: Pedagogia de Paulo Freire, Participação Popular e Educação Permanente, sempre os relacionando à construção da Terapia Comunitária.

\subsection{PARTICIPAÇÃO POPULAR}

Pensar em Promoção da Saúde é pensar em Participação Popular, que representa na verdade, uma conquista no processo de democratização no Brasil. A partir da Constituição de 1988, vê-se um amparo no que diz respeito à participação da população nas políticas de saúde no Brasil. Sobretudo no Sistema de Saúde, segundo Ferla (2004), os espaços de participação popular têm trazido inúmeras contribuições, e têm se chocado com a atenção medicalizadora, resultante do modelo biomédico. Essas contribuições vêm, entre outras coisas, a partir das idéias de interdisciplinaridade, participação horizontal e propositiva do usuário e da população.

Os debates constantes de como se promover a saúde, leva-nos a pensar que a interlocução entre os mais diferentes atores sociais, por meio de um diálogo verdadeiro e democrático é o caminho mais rápido. O direito à saúde está intrinsecamente ajustado ao apoio, participação e pressão dos setores populares. Em outras palavras, para que a saúde seja garantida, a própria população deve se

\footnotetext{
${ }^{6}$ http://ead.nesprom.unb.br/course/view.php?id=24
} 
articular para fazer valer o reconhecimento e a efetivação desse direito. Destarte será possível que essa população identifique o projeto de qualidade de vida que ela precisa, merece e deseja.

Segundo Sposati \& Lobo (1992, p. 637), o direito à saúde não é somente a "democratização do consumo de assistência médica", é algo muito mais complexo. O mesmo sujeito que é usuário/consumidor é também sujeito/democrático. São coisas que não se separam, mas sim o contrário, se retroalimentam. Portanto, a participação popular - ou controle social nas políticas públicas de um modo geral, é que vai garantir a efetivação e cumprimento de seu papel dentro da concepção de saúde como um produto social e histórico condicionado pela condição de vida e trabalho das pessoas.

Ora, se falamos em diálogo verdadeiro e democrático, falamos num diálogo despido do rigor hierárquico, onde uns sabem mais que outros. Portanto lembramonos do espaço democrático e popular das $\operatorname{Rodas}^{7}$ de Terapia, cujo objetivo sempre é o da escuta ativa, aquela livre de juízo de valor, onde cada um é parte integrante do imbricado sistema coletivo, sendo, portanto tão valoroso quanto o outro. Nesse espaço, não há lugar para o 'transferir conhecimento'. Como dizia Paulo Freire (1996), ensinar não é transferir conhecimento, mas sim, criar possibilidades para a própria produção/construção do conhecimento.

Se na verdade, o sonho que nos anima é democrático e solidário, não é falando aos outros, de cima para baixo, sobretudo, como se fôssemos os portadores da verdade a ser transmitida aos demais, que aprendemos a escutar, mas é escutando que aprendemos a falar com eles. Somente quem escuta paciente e criticamente o outro, fala com ele, mesmo que, em certas condições, precise de falar a ele (FREIRE, 1996, p. 113).

Podemos dizer que Controle Social ou Participação Popular é, grosso modo, a capacidade que tem a sociedade organizada de intervir nas políticas públicas, interagindo com as esferas públicas na definição de prioridades e na elaboração de planos de ação do Município, Estado ou Governo Federal. Os Conselhos de um modo geral são uma forma democrática de Controle Social. Fazer valer esse canal de participação é tarefa e direito de cada cidadão e dever do Estado.

Vale lembrar aqui Antônio Ivo de Carvalho (1995), quando diz que a idéia de comunidade hoje está bem mais afastada daquela criada nas décadas de 50 e 60,

\footnotetext{
${ }^{7}$ Nota da Autora: Como são chamados os encontros na TC. Os participantes se distribuem em círculo - roda.
} 
nos Estados Unidos. Não se trata mais de uma visão 'empobrecida' e cuja definição trazia a idéia "naturalizada" de comunidade que, por se tratar de um agrupamento de indivíduos que vivem num mesmo local, necessariamente haveriam de compartilhar os mesmo ideais e também teriam predisposição/desejo de solidariedade. Partindose desse ponto de vista a comunidade teria em suas mãos (e, portanto passa a ser responsável) a capacidade de unida, combater a pobreza e melhorar os níveis de saúde; a idéia do self-mad man está agora com uma nova roupagem (a coletiva).

Trata-se assim de uma concepção autárquica da comunidade que abstrai sua inserção no contexto sócio-econômico mais amplo. A comunidade poderá combater a pobreza e a doença em função da sua capacidade de se unir, se organizar, se esforçar, numa versão coletiva da idéia do self-mad man. A participação é fetichizada como o passaporte para as melhorias sociais (CARVALHO, 1995, p. 17).

Com as cartas de saúde e todo o debate promovido a partir delas, busca-se promover condições para despertar nos governos a idéia de ações integradoras, complementares, buscando de forma consciente colocar a população para participar dos processos decisórios. Deste modo, não se trata mais de indivíduos lutando contra um Estado ausente, com políticas perversas que têm a lógica de reforçar as fendas sociais, as gigantes disparidades de distribuição de renda. O que começa a surgir agora são sujeitos mais conscientes, com desejo de participação, e participação crítica, trazendo para si a necessidade de cooperar. Surge a participação como e com cidadania, Carvalho (1995, p. 25). Esses novos atores sociais buscam a democratização da saúde, a universalização dos direitos sociais, a busca incessante por um novo conceito de cidadania.

Lefèvre (1999), refletindo sobre o sujeito da promoção da saúde, diz-nos que são homens e mulheres, movimento social, usuário/cidadão, Estado, ou seja, todos os atores sociais que, direta ou indiretamente estão envolvidos com a PS. E acrescenta, de forma brilhante, que esse sujeito deve estar socialmente e não apenas tecnicamente preparado para provocar transformações, visto que a PS por pretender ser uma intervenção social transformadora, necessita de sujeitos capazes de realizar esta transformação. É o que chamamos anteriormente de sujeitos conscientes do seu papel transformador. 


\subsection{EMPOWERMENT}

Também lembramos o conceito de empowerment ${ }^{8}$ ao falar sobre a construção da Promoção da Saúde, uma vez que segundo Sérgio Resende Carvalho (2004), este conceito é um eixo central da PS. Trata-se de conceito complexo, cuja raiz está no processo de desenvolvimento social ocorrido na segunda metade do século $X X$, como por exemplo: a luta pelos direitos civis, o movimento feminista, entre outros. Passou também pela influência dos movimentos de auto-ajuda e da própria psicologia comunitária. Então, de alguma forma, diz sobre o reconhecimento das próprias forças e habilidades. É quando o sujeito passa por uma transformação pessoal que o habilita a 'caminhar' com mais autonomia. De certa forma isso ocorre quando o assistencialismo dá lugar ao desenvolvimento, ao crescimento.

Por outro lado, ainda citando Carvalho (2004), deve-se cuidar para que a idéia de "empowerment" não traga a noção desavisada de autonomia das pessoas de certa forma que justifique a ausência do Estado em momentos que este não deva se ausentar.

Isso vem permitindo que, embora expresso na linguagem que afirma importância da autonomia das pessoas e da diminuição da dependência de instituições macrossociais, o "empowerment" psicológico venha sendo usado para justificar a diminuição e o retrocesso na prestação de serviços sociais e de saúde em tempos de conservadorismo fiscal. Nos Estados Unidos, por exemplo, políticas de corte neoliberal vêm combinando a noção de "empowerment" com a ideologia política da responsabilidade pessoal para sugerir que as pessoas façam, cada vez mais, uso de seus recursos próprios e/ou da comunidade antes de recorrer à ajuda de instituições estatais (CARVALHO, 2004, p. 1091).

Cabe aqui uma breve digressão com o sentido de lembrar que as políticas neoliberais levaram o Estado à prática de transferência de responsabilidade às associações e instituições não-governamentais (GOHN, 2005), e assim vimos emergir o Terceiro Setor. É a sociedade civil tomando para si a responsabilidade do Estado, e este se desresponsabilizando e omitindo. Esta visão é assaz perigosa uma vez que traz uma idéia distorcida de 'autonomia do sujeito'. O que numa leitura

\footnotetext{
${ }^{8}$ Nota da Autora: este termo não conta com uma tradução única em português, o que nos levará a manter a escrita em inglês. Na língua inglesa o significado é "the process of giving somebody the power of act" (Oxford Advanced Learner's Dictionary, 1995). O empowerment é uma abordagem de projeto de trabalho que objetiva a delegação de poder de decisão, autonomia e participação dos funcionários na administração das empresas. Busca-se o comprometimento dos empregados em contribuir para as decisões estratégicas, com o objetivo de melhorar o desempenho da organização (Rodrigues; Santos, 2004).
} 
míope e linear pode parecer algo bom, como o estímulo à autonomia, à independência, à liberdade de escolha etc, é na realidade uma forma cruel que o Estado encontra para se descompromissar em relação às políticas públicas sociais.

A despeito das críticas que podemos encontrar em relação à idéia de "empowerment", lembramos que sob a influência de Paulo Freire vários teóricos do mundo vêm indicando como modelo pedagógico eficaz o "empowerment comunitário". Este modelo, segundo Carvalho (2004), assume o papel de "educação como prática da liberdade", busca o rompimento com métodos educativos cartesianos para pensar em métodos que dêem valor ao debate e a discussão de idéias, com uma visão crítica da realidade. Portanto é um método que contribui para a emancipação do sujeito.

Sob a influência de Paulo Freire, os teóricos do "empowerment comunitário" vêm preconizando a efetivação de um modelo pedagógico que assuma a "educação como uma prática da liberdade". Este projeto, que alguns denominam de "empowerment education" e que poderia ser igualmente denominado de "educação popular" e/ou "educação para a transformação", procura romper com métodos educativos centrados no exercício do "poder sobre" o outro, substituindo-o por métodos que valorizem o debate e a discussão de idéias, opiniões e conceitos com vistas à solução de problemas ("poder com"). O "empowerment education" busca, portanto, contribuir para a emancipação humana por meio do desenvolvimento do pensamento crítico e o estímulo a ações que tenham como objetivo realizar a superação das estruturas institucionais e ideológicas de opressão (CARVALHO, 2004, p. 1093).

Dentro desta visão de "empowerment comunitário", desenvolvida a partir das contribuições de Paulo Freire, entendemos que a Terapia Comunitária é um espaço de fortalecimento do sujeito, da reflexão e construção de um pensamento crítico. É como diz Adalberto Barreto (2008), um espaço onde é estimulada a participação social de maneira a dinamizar as relações sociais, para que sejam promovidos a conscientização e estímulo do grupo. Em acréscimo, este é um dos objetivos da TC, promover um espaço de diálogo e de reflexão, para que a comunidade tome iniciativas em seu favor, gerando assim sujeitos agentes da sua própria transformação e da transformação social.

Segundo Barreto (2008), a TC está calcada na certeza de que a solução para os problemas está sempre no coletivo e em suas interações, por isso busca romper com a idéia do clientelismo para promover o surgimento ou (re)surgimento da cidadania, momento este que o indivíduo deixa de ser um objeto passivo de intervenção para se transformar em sujeito ativo da sua própria história. 


\subsection{EDUCAÇÃO PERMANENTE}

Outro caminho muito importante que contribui para a construção da Promoção da Saúde é a Educação Permanente.

Trata-se de uma política nacional cuja proposta é transformar e qualificar a atenção à saúde bem como incentivar a prática e a organização das ações e serviços de saúde. Para que esta política seja implantada, necessário se faz que seja articulado um trabalho entre o sistema de saúde e as instituições de ensino. Segundo Ceccim (2005), a Educação Permanente em Saúde (EPS) é uma das mais nobres metas estabelecida pela saúde coletiva, cujo propósito maior é transformar a rede pública de saúde em uma rede de ensino-aprendizagem na tarefa do trabalho.

Desta forma, como destaca Roschke (2003), a EPS é a aprendizagem que se faz no trabalho, onde o aprender e ensinar se ajuntam no dia-a-dia das organizações e do trabalho. É o aprender no fazer e o fazer aprendendo. Portanto é importante que as mudanças nas estratégias de organização sejam desenvolvidas/construídas indiscutivelmente, na prática concreta das equipes, lembrando, contudo, de respeitar o contexto sócio-histórico-cultural onde os atores sociais estão inseridos.

Quando falamos em Educação Permanente necessariamente falamos de uma formação diferenciada, democrática. Falamos de um projeto político-pedagógico, que nas palavras de Alves; Sauper (2000, p. 64) "deve ser construído de forma democrática, participativa, de debate e diálogo", e ainda citando estes autores:

São inúmeras as iniciativas individuais, grupais e mesmo institucionais, que tem proposto e desenvolvido programas e projetos nos quais o valor maior está na interação, no respeito, no diálogo, na liberdade, na emancipação, na valorização das crenças e da cultura (ALVES; SAUPE, 2000 , p. 65).

A EPS deve ser estruturada a partir da problematização do processo e qualidade do trabalho, onde as necessidades de capacitação podem ser identificadas. Assim, sendo pautadas nas necessidades reais dos trabalhadores e da população, pode se garantir a aplicabilidade dos conteúdos e tecnologias estabelecidas.

Ainda segundo Ceccim (2005), a EPS configura-se, para vários educadores, como um desdobramento da Educação Popular de Paulo Freire. De fato, se a EPS está pautada no pressuposto de que tem que promover e produzir sentido, ela diz respeito à aprendizagem significativa de Paulo Freire. A EPS acontecendo no dia-a- 
dia, ou seja, no espaço real dos acontecimentos, não pode ser pensada apenas em seus aspectos técnicos, pois que envolve transformação nas relações, no trabalho (processos) e também nas pessoas.

A aprendizagem significativa vai muito além de programas de capacitação e/ou da atualização dos recursos humanos, trata-se de entender o que é EPS.

A Educação Permanente em Saúde constitui estratégia fundamental às transformações do trabalho no setor para que venha a ser lugar de atuação crítica, reflexiva, propositiva, compromissada e tecnicamente competente. Há necessidade, entretanto, de descentralizar e disseminar capacidade pedagógica por dentro do setor, isto é, entre seus trabalhadores; entre os gestores de ações, serviços e sistemas de saúde; entre trabalhadores e gestores com os formadores e entre trabalhadores, gestores e formadores com o controle social em saúde. Esta ação nos permitiria constituir o Sistema Único de Saúde verdadeiramente como uma rede-escola (CECCIM, 2005, p. 976).

Sendo a EPS uma articulação entre as necessidades do trabalho e da aprendizagem, e tendo por objetivo promover possibilidades de superação e/ou solução dos problemas que são diariamente enfrentados na realidade do trabalho, ela deve ser pensada por todos os atores sociais, públicos ou privados, que estão relacionados com a questão da saúde. E buscar fortalecer ou estabelecer essas redes sociais é indispensável para que esta aprendizagem seja significativa para todos os atores. Pensar em aprendizagem significativa é também pensar em diálogo. Segundo Freire (2005), o diálogo é instrumento imprescindível de relações sociais transformadoras e de acordo com ele, a barreira entre os homens é uma barreira puramente ideológica que nos foi imposta pela classe dominante, por isso urge rompermos com a idéia de que existe uma diferença entre os homens que possa ir além do fato de alguns possuírem mais experiência acadêmica do que outros.

Mas se dizer a palavra verdadeira, que é trabalho, que é práxis, é transformar o mundo, dizer a palavra não é privilégio de alguns homens, mas direito de todos os homens. Precisamente por isto, ninguém pode dizer a palavra verdadeira sozinho, ou dizê-la para os outros, num ato de prescrição, como o qual rouba a palavra aos demais (FREIRE, 1997, p. 9091).

Nessa perspectiva de educação significativa, também a Terapia Comunitária nos orienta que os sujeitos têm seus saberes e que o diálogo verdadeiro se dá no encontro dos homens para ser mais, como também nos coloca Paulo Freire. Assim como a EPS, a TC também tem como proposta um 'aprender/ensinar' democrático e 
participativo, pois acredita que ninguém ensina ninguém, ninguém aprende sozinho, o homem aprende no encontro que estabelece com o outro. 


\section{TERAPIA COMUNITÁRIA}

Pensamos a Terapia Comunitária como espaço privilegiado, construtor de cidadania, que possibilita a franca construção de redes solidárias. Por tratar-se de um espaço democrático de trocas de experiências entre membros de uma determinada comunidade e de ferramenta de fácil aplicabilidade, pode ser desenvolvida em qualquer espaço: Institucional, Educacional e Comunitário, entre outros e por membros dos mais diversos grupos sócio-econômico-culturais. Deste modo, a TC é compreendida por ser um instrumento Promotor de Saúde, uma vez que em seus espaços são discutidos, estimulados e compreendidos valores como: cidadania, cuidado, educação, equidade, vida, saúde, democracia, solidariedade e participação.

$\mathrm{Na}$ Terapia Comunitária, os sujeitos são convidados a participar, dividir suas experiências: dores e alegrias. Assim, as informações circulam num modelo que Adalberto Barreto (2008) chama de co-participativo .

(...) neste tipo de abordagem, é sabido que se alguém vive hoje uma depressão, outra pessoa já pode ter passado por situação semelhante e convivido com esse mesmo tipo de sofrimento, e, assim, pode falar de suas dificuldades e, sobretudo, de como as superou. Ou ainda, se alguém nunca viveu algo parecido, pode informar-se e prevenir-se, caso algum dia, conviva com este problema (BARRETO, 2008, p. 58).

Podemos então dizer que uma vez que promove a divulgação de informações às mais diversas - intra-grupo, a TC vai promover também a possibilidade de determinada comunidade se fortalecer e, quiçá, a divulgação de informações aguilhoará a comunicação de diferentes setores da comunidade e num segundo momento, da própria sociedade, estimulando a intersetorialildade. Em acréscimo, trazemos a seguinte reflexão.

(...) viver entre as pessoas de modo humano, pressupõe a capacidade de escapar do domínio da pura necessidade para um espaço que é qualitativamente diferente - o espaço da ação e do discurso, onde as pessoas realizam sua capacidade para falar e agir (ARENDT In JOVCHELOVITCH 2002 p. 67).

Ainda de acordo com Jovchelovitch (2002), exatamente porque as pessoas são diferentes entre si, a ação e o discurso são tão necessários. Segundo ela, na experiência da pluralidade, da diversidade existente entre os sujeitos, com

\footnotetext{
${ }^{9}$ Este modelo se apóia na competência das pessoas. Quem tem problemas tem, também, soluções (Barreto, 2008, p. 58).
} 
expectativas distintas, é possível chegar-se ao entendimento e ao consenso. Portanto, é a experiência da TC que, ao aglutinar os mais diferentes sujeitos, traz a possibilidade de a partir da fala (do discurso), colocar seus questionamentos e possibilidades e assim possibilitar aos participantes a tomada de consciência do poder transformador de cada um - e de cada comunidade. A partir daí será possível o fortalecimento da comunidade que, tendo espaço para atuar, opinar e discutir, pode realizar ações que sejam de seu interesse.

A Terapia Comunitária tem testemunhado ao longo dos anos, o surgimento de processos individuais e também coletivos de auto-soluções e auto-inovações. Isso é possível porque a TC despreza as dicotomias entre o individual e o social, bem como recusa o modelo 'salvador da pátria'10, aquele que gera dependência e que, segundo Barreto (2008), é grande dificultador no processo de crescimento e autonomia humana e comunitária/social. Compartilhamos com a idéia de Barreto, no sentido de compreender que o modelo co-participativo produz sentido e significado no sujeito, estimula a autonomia e provoca o senso de co-responsabilidade. Estimula o resgate das competências individuas e sociais em detrimento das carências e promove relações horizontalizadas, onde o sujeito deixa de ser 'objeto' passivo de intervenção para tornar-se um sujeito ativo, capaz e 'empoderado'. Tudo isso provoca mudança nas relações. Este modelo possibilita ir além do privado para o público.

(...) a reflexão dos problemas sociais que atingem os indivíduos sai do campo privado para a partilha pública, coletiva, comunitária. A ênfase no trabalho de grupo, para que juntos partilhem problemas e soluções e possam funcionar como escudo protetor para os mais vulneráveis, sendo instrumentos de agregações e inserção social. Nós afirmamos que a solução está no coletivo e em suas interações, no compartilhar, nas identificações com o outro, no respeito às diferenças. Os profissionais devem ser parte desta construção. Ambos se beneficiam - a comunidade gerando autonomia e inserção social e os profissionais se curando do "autismo institucional e profissional", bem como de sua alienação universitária (BARRETO, 2008, p. 61).

Sendo a Terapia Comunitária este espaço privilegiado, construtor de cidadania, e promotor de construção de redes solidárias e de fortalecimento e 'empowermet' da comunidade - dentro dos moldes da visão de "empowerment comunitário" desenvolvido a partir das contribuições de Paulo Freire - ela cria a base

\footnotetext{
${ }^{10}$ Nota da Autora: segundo Adalberto Barreto este modelo privilegia o individual, as carências e baseia-se tão somente no aspecto negativo das coisas e pessoas, despertando no sujeito sentimentos de inadequação, incapacidade e insegurança.
} 
para o controle social, entendido como fenômeno complexo, humano e que vai muito além da mera mobilização. Controle este, possível quando da construção da autonomia e responsabilidade de todos os atores sociais envolvidos o que só pode emergir a partir do respeito profundo às diferenças de idéias e posições, por mais antagônicas que sejam. Como entendido na concepção de educação significativa de Paulo Freire, longe das amarras do autoritarismo e da negação da capacidade do próprio sujeito.

$\mathrm{Na}$ TC os sujeitos são de tal forma respeitados nas suas singularidades que, seguramente, passam a acreditar mais nos próprios saberes, oriundos da experiência única de cada um. Não se trata aqui de desacreditar ou desqualificar o saber acadêmico, mas, sobretudo, de perceber que diversos são os saberes, todos igualmente importantes na nossa cultura e na vida diária de cada um de nós.

(...) em qualquer deles, porém, subestimar a sabedoria que resulta necessariamente da experiência sócio-cultural é, ao mesmo tempo, um erro científico e a expressão inequívoca da presença de uma ideologia elitista. Talvez seja mesmo o fundo ideológico escondido, oculto, opacizando a realidade objetiva, de um lado, e fazendo, do outro, míopes dos negadores do saber popular, que os induz ao erro científico. Em última análise, é essa "miopia" que, constituindo-se em obstáculo ideológico, provoca 0 erro epistemológico (FREIRE, 1992, p. 85).

Então, respeitar os saberes dos sujeitos que chegam à Roda de TC, suas crenças e sua visão de mundo, dá a esses sujeitos a oportunidade ímpar de 'irem além'. Em outras palavras, o que a TC faz é auxiliar o sujeito a se fortalecer, "empoderar", desta forma é possível que ele faça a escolha de utilizar-se de instrumentos adequados (participação social/controle social; educação permanente e significativa, e outros) para construir uma vida com mais qualidade, oportunidades, com melhores condições de estudo e trabalho, diminuindo as desigualdades sociais resultantes da perversa distribuição de renda e possibilidades. Deste modo estamos convencidos que a TC é uma ferramenta extraordinária na construção e desenvolvimento da Promoção da Saúde

A Terapia Comunitária está apoiada teórica e conceitualmente nos seguintes pilares: Pensamento Sistêmico, Teoria da Comunicação, Antropologia Cultural, Resiliência e Pedagogia de Paulo Freire. Vejamos agora de forma sucinta cada um desses pilares teóricos conceituais, com especial ênfase na Pedagogia de Paulo Freire, por sua absoluta conformidade com a Promoção da Saúde. 


\subsection{PENSAMENTO SISTÊMICO}

O Pensamento Sistêmico rompe com vários paradigmas, levando-nos a entender a dinâmica das interações existentes num contexto, seja social, familiar, organizacional, etc. Assim, o pensamento sistêmico nos orienta a compreender que a sociedade/comunidade não é apenas o resultado da soma de vários indivíduos, mas a relação que se estabelece entre eles.

Um dos precursores da idéia de Pensamento Sistêmico foi Bertalanffy, cujas investigações levam a compreender a complexidade dos sistemas e sintomas (MATTELART, 1999). Essa abordagem valoriza o caráter complexo dos sistemas e comportamentos, de maneira que um sempre irá influenciar o outro, por isso é uma abordagem tão utilizada na psicologia e nas ciências sociais como um todo. Como compreender a problemática de uma família sem buscar entender/enxergar o sistema como um todo? (a sociedade, a cultura, os papéis de cada um dos seus membros, o aspecto financeiro, emocional, seus valores e crenças, etc).

Insistir num modelo linear, de causa e efeito, com visão estanque dos problemas, parece não ser útil, sobretudo para quem trabalha nas comunidades, diretamente com os sujeitos que estão indiscutivelmente interligados, numa rica e complexa experiência de vida.

Pensar sistemicamente, é pensar interdisciplinarmente, é entender que todas as partes estão se construindo e sendo construídas simultaneamente. É compreender que nas micro ou macro relações, todos os sujeitos são parte do problema e também parte da solução. Nesse sentido, Adalberto Barreto define da seguinte forma o pensamento sistêmico:

(...) o pensamento sistêmico, à medida que postula as relações de interdependência entre seus membros, ao compreender um problema, considera-o também no contexto das inter-relações. Sendo assim [...] todos os envolvidos participam dele [...], portanto, não se pode atribuir a sua existência a apenas um dos participantes (BARRETO, 2008, p. 192).

Desta forma identificamos que este pilar da Terapia Comunitária está bem próximo da compreensão de Promoção da Saúde. Na PS também se procura a interdisciplinaridade como sustentação deste movimento, quando se busca as parcerias interinstitucionais, que, segundo Buss (2003), trabalham com a noção de responsabilização múltipla, seja pelos problemas, seja pelas soluções propostas para os mesmos. A intersetorialidade é a negação da fragmentação das políticas 
e/ou ações na saúde, no sentido de integrar as diversas experiências e saberes no campo da saúde. Destarte é na TC, onde se busca integrar as mais variadas experiências e saberes, pois que é a relação que confere sentido à vida.

Buscar essa visão sistêmica é vislumbrar a construção do paradigma de saúde integral, Alves; Polônia (2003, p. 216) "rompe com a noção de fragmentação do sujeito, e o contextualiza, considerando suas expectativas, sonhos, hábitos, condições de vida, processos familiares e afetivos".

\subsection{TEORIA DA COMUNICAÇÃO}

Quando falamos em comunicação, pensamos rapidamente nos 5 elementos tradicionalmente elencados como componentes do processo de comunicação: Emissor, Receptor, Mensagem, Código e Canal (RAMISTHALER, 2006), mas aqui queremos ir bem além. Pensar na comunicação como componente que pode agregar ou separar pessoas, seja na família, na escola, na comunidade, na organização.

(...) a riqueza e a variedade das possibilidades de comunicação entre as pessoas nos convidam a ir além das palavras, para entender a busca desesperada de cada ser humano pela consciência de existir e pertencer (BARRETO, 2008, p. 28).

Deste modo, é interessante também lembra Savater (2001), quando fala da importância do sentimento de pertencimento que o sujeito precisa encontrar num grupo para de fato crescer com ele.

É necessário certo grau de disposição para a efetivação de uma comunicação efetiva, um diálogo direto e transparente, que minimize os problemas que se estabelecem nos diversos espaços de relações. A Terapia Comunitária estimula exatamente a manutenção ou criação do diálogo efetivo, sem julgamentos ou aconselhamentos (são essas, duas regras da TC). Um provérbio muito utilizado na TC é: "quando a boca cala, os órgãos falam, quando a boca fala, os órgãos saram" Barreto (2008, p. 66). De fato, o papel da TC é estimular os sujeitos para que falem, se coloquem, assim a informação vai circular e todos sairão mais crescidos/amadurecidos do processo.

Também na construção da Promoção da Saúde, é necessário um diálogo interdisciplinar e efetivo entre os mais diferentes setores da sociedade, com a finalidade de mobilizar a todos na construção e implementação de ações que 
concretizem a PS. No artigo: o processo de trabalho da enfermagem em saúde coletiva e a interdisciplinaridade, encontramos uma discussão, cujo objetivo é ocasionar reflexões sobre a necessidade de um diálogo interdisciplinar sempre que o trabalho disser respeito ao processo saúde-doença-cuidado.

A transdisciplinaridade baseia-se na possibilidade de comunicação não entre campos disciplinares, mas entre agentes em cada campo, através da circulação não dos discursos, mas dos sujeitos dos discursos. Não são os campos disciplinares, entidades abstratas (conceitos, noções, modelos) que interagem entre si, mas os sujeitos que os constroem na prática científica cotidiana (ALMEIDA FILHO In ROCHA; ALMEIDA, 1997,p. 99).

\subsection{ANTROPOLOGIA CULTURAL}

A Antropologia surge no século XIX e concretiza-se como ciência trazendo a preocupação de estudar a origem do homem civilizado (GODOY, 2004). Neste campo, o conhecimento a respeito do homem e, com diz Godoy (2004, p. 31), "sobre as culturas, indicam um momento de projeção de saberes que se impõem como marca de evolução da crítica rumo a um maior humanismo na ciência".

A Antropologia Cultural é um dos pilares da Terapia Comunitária, visto que trata de compreender as diferentes culturas e saberes de determinado povo. Essa diversidade, se reconhecida e respeitada, será um suporte extraordinário no sentido de levar o sujeito a se afirmar enquanto sujeito capaz.

(...) se a cultura for vista como um valor, um recurso que deve ser reconhecido, valorizado, mobilizado e articulado de forma complementar com outros conhecimentos, poderemos ver que este recurso nos permitirá somar, multiplicar nossos potenciais de crescimento e de resolução de nossos problemas sociais e construir uma sociedade mais fraterna e justa (BARRETO, 2008, p. 29).

Para Fleuri (2002), diante do processo de globalização mundial, as relações estão cada vez mais transnacionais. Desta forma o encontro entre diferentes sujeitos, de culturas as mais diversas possíveis são cada vez mais comuns, levandoos a confrontarem suas diferenças. Isso promove possibilidades de crescimento e amadurecimento.

Surge, ao mesmo tempo, a necessidade de um grupo abrir-se e de construir relações de reciprocidade com outros. Surge, então, a possibilidade de um movimento cidadão: os diferentes grupos e indivíduos articulam-se sob a forma de redes e parcerias, onde a complementaridade se constrói a partir do respeito às diferenças. Este é o campo das relações interculturais (FLEURI, 2002, p. 67). 
Ainda lembrando Fleuri (2002), a despeito da educação intercultural estar configurada como uma pedagogia do encontro, apontando para a promoção de experiências densas e complexas, onde o encontro e/o confronto das mais diversas narrativas promove uma possibilidade extraordinária de crescimentos para todos os sujeitos envolvidos, são poucos os estudos e discussões sobre esta proposta educativa.

Por ser a Terapia Comunitária um local democrático de troca de experiência/informação, ajuda a promover a articulação dos saberes e culturas e estimula os sujeitos a conviverem com as diferenças. O que em última análise, leva à construção de uma sociedade mais tolerante no que diz respeito à pluralidade de culturas, saberes, valores e crenças.

\subsection{RESILIÊNCIA}

Resiliência é um conceito oriundo da física que diz respeito à capacidade que determinados materiais têm de, após serem submetidos a determinada tensão, voltarem ao seu estado de origem quando aquilo que o tensionava é eliminado. Esse conceito foi importado da física pela psicologia no sentido de entender a capacidade que determinados sujeitos têm de lidar com conflitos, dores, problemas; suportar grandes adversidades e demonstrar aprendizado e superação. Ainda mais, como determinados sujeitos a despeito de vivenciarem dificuldades extremas - guerras, violências/torturas físicas e/ou emocionais, conseguem manter a sua inteireza (WALSH, 2004).

Nas palavras de Walsh (2004, p. 26), resiliência é a capacidade "de uma pessoa sair da adversidade fortalecida e dona de maiores recursos. Trata-se de um processo ativo de resistência, adaptação e crescimento como resposta às crises e aos desafios da vida".

$\mathrm{Na}$ verdade trata-se de uma habilidade para enfrentar as dificuldades. Desta forma, (LAZARUS 1966. In GIMENEZ 1997), entende o enfrentamento como um conjunto de estratégias a serem utilizadas para lidar com determinada ameaça. Segundo Barreto (2008) é importante que a comunidade seja estimulada e encorajada a buscar alternativas de enfrentamento diante de suas dificuldades e carências, não no sentido de substituir as políticas públicas, mas ao contrário, no sentido de inspirar políticas ou mesmo reorientá-las. 
A Terapia Comunitária é, segundo seu idealizador, um espaço promotor de resiliência uma vez que pela partilha de experiência é possível que o sujeito que participa da Roda, reforce sua auto-estima, estimule sua autonomia e fortaleça os vículos afetivos com outros sujeitos. Tudo isso ajuda o sujeito a criar novas habilidades de enfrentamento. Em acréscimo, lembramos Barreto (2008, p. 71), "cada pessoa vem participar da Roda de TC com uma certeza, com uma visão de mundo, e sai enriquecida porque se confronta com outras visões de mundo".

$\mathrm{Na}$ verdade, tudo isso leva o sujeito, sua comunidade e sua cidade, a desenvolver habilidades para enfrentar seus problemas. Fortalecendo-se na aprendizagem estabelecida nos encontros de TC, estarão mais habilitados a encontrar soluções para promover saúde, melhorar a qualidade de vida a partir de valores como cidadania, educação, equidade, democracia e solidariedade.

Como desprezamos as dicontomias existentes entre o social e o individual, lembramos que a capacidade do sujeito de produzir sentido ante seus conflitos é um aprendizado individual e social/cultural ao mesmo tempo. De acordo com Fernando Rey (2003), o sujeito deve ser compreendido a partir da recuperação do caráter complexo e dialético do homem que, ao mesmo tempo que representa uma singularidade, também representa um ser social. Em outras palavras, o grau de resiliência de um sujeito diz respeito a fatores ambientais, sociais e individuais.

\subsection{PEDAGOGIA DE PAULO FREIRE}

Paulo Freire nasceu em Pernambuco em 19 de setembro de 1921. Advogado e professor, desde cedo preocupou-se com a formação de jovens e adultos trabalhadores. De acordo com Freitas (2004, p. 28), foi considerado "subversivo internacional e traidor de cristo e do povo brasileiro" e em 1964 foi exilado para o Chile. Durante cinco anos, no Chile, trabalhou em seu projeto e escreveu sua principal obra: Pedagogia do Oprimido, cujo conteúdo o fez ficar conhecido mundialmente, por se tratar de obra de riqueza ímpar, que aborda questões educacionais, culturais, políticas, sociológicas, da importância da comunicação e claro, sobre a liberdade. Como se dá a liberdade? Como fazer para conseguí-la?

A Pedagogia de Paulo Freire é um dos eixos teóricos da Terapia Comunitária. Aspectos da fundamentação teórica de Paulo Freire como, por exemplo, a associação entre a realidade vivida pelo educando e a teoria, é fundamental, pois 
segundo Barreto (2008), a prática educativa só terá sentido se possibilitar ao educando e ao educador assumirem-se como sujeitos sócio-histórico-culturais. A educação não se dá num processo estanque e não tem fim, o ser humano é inacabado, está em processo. É como diz Freire (1996, p. 50): "na verdade, o inacabamento do ser ou sua inconclusão é próprio da experiência vital. Onde há vida, há inacabamento".

Assim como no método de Paulo Freire onde o educador sincero e verdadeiro, só poderá assumir sua missão se tiver apreço, carinho e respeito por ela, o Terapeuta Comunitário também só será útil se tiver envolvimento e amor pelo que faz. Se chamamos atenção para a Pedagogia do Oprimido, é tão somente por ela estar na raiz da Terapia Comunitária. Portanto, tornar-se consciente do seu papel é passo imprescindível para que o terapeuta comunitário realize sua missão, pois como coloca Barreto (2008), quem haverá de duvidar que a Pedagogia da Terapia Comunitária seja na realidade a Pedagogia do Oprimido?

Via de regra é esse sujeito oprimido e silenciado que busca a Terapia Comunitária como, muitas vezes, o último recurso para o alívio do seu sofrimento. E o papel da TC é justamente o de acolher esse sofrimento e criar condições para que os participantes enxerguem por si mesmos, caminhos alternativos. Isso é muito provável de acontecer, uma vez que é na troca que o homem se constrói.

A partir desta troca de experiência emerge as mais variadas soluções, até mesmo contraditórias. Temos que ter cuidado para não buscar um consenso, pois este desencadearia a luta pelo poder e destruiria a construção coletiva feita com a colaboração de todos. Não existe verdade, mas leituras diferentes da realidade. E cada um leva o que pode, a partir do seu contexto sócio-econômico-cultural (BARRETO, 2008, p. 288).

O Terapeuta Comunitário, como dito anteriormente, não é um especialista, uma vez que na TC busca-se o distanciamento desta hierarquização do saber. Assim, aproveitamos para fazer um paralelo em relação à pedagogia freireana, onde o educador não é aquele que detém o saber, mas um facilitador de descobertas.

Também no movimento da Promoção da Saúde, buscamos identificar consonâncias com a pedagogia de Paulo Freire, neste recorte especificamente, com a tomada de consciência da realidade; na educação permanente, por exemplo, busca-se a horizontalização dos saberes e práticas, a negação do modelo vertical e linear, o que Paulo Freire considerava educação bancária e mais, pensa-se em um modelo participativo, onde a confiança e a determinação das pessoas geram 
compromisso e participação dos envolvidos. Lugar onde todos possam tomar consciência da realidade.

A investigação temática se faz a partir do esforço comum para a tomada de consciência da realidade e para a autoconsciência. Isso a caracteriza como ponto de partida do processo educativo ou da ação cultural libertadora. [...] Investigar o "tema gerador" é investigar o pensar dos homens situados na realidade, que é sua práxis (NOVOA, 1981, p. 101).

No método de conscientização de Paulo Freire o homem aprende a exercer sua liberdade. Este método nos faz entender a educação como prática libertadora. Nesta pedagogia faz-se da opressão objeto de reflexão dos oprimidos, seu engajamento na luta por sua libertação e na práxis que implica a ação e a reflexão dos homens sobre o mundo para transformá-lo. É ajudar o homem a assumir a percepção de que pode mudar o mundo, percebendo que a educação é uma espécie de hino à liberdade. Para Paulo Freire, o direito de saber é um direito que nos acompanha desde o nascimento até a morte. Negar o direito ao saber é desumano e cruel, é negar a própria vida (FREIRE, 2005).

Tanto na construção da Promoção da Saúde, como na Terapia Comunitária, o que encontramos é uma necessidade enorme de respeitar os saberes, a compreensão de mundo de cada sujeito. Exercitar a escuta e buscar somar as ricas experiências de sujeitos os mais diferentes possíveis.

Em nenhum momento Paulo Freire disse, como sugerem seus críticos, que o educador, no intento de respeitar o saber dos seus educandos, devem ficar girando, em torno dos saberes do senso comum, cuja superação não seria tentada. O que Freire nos coloca claramente é que jamais devemos deixar de lado o que os educandos (sujeitos, crianças ou adultos), trazem consigo - sua compreensão de mundo.

(...) o que tenho dito sem cansar, e redito, é que não podemos deixar de lado, desprezado como algo imprestável, o que educandos, sejam crianças chegando à escola ou jovens e adultos a centros de educação popular, trazem consigo de compreensão do mundo, nas mais variadas dimensões de sua prática na prática social de que fazem parte. Sua fala, sua forma de contar, de calcular, seus saberes em torno do chamado outro mundo, sua religiosidade, seus saberes em torno da saúde, do corpo, da sexualidade, da vida, da morte, da força dos santos, dos conjuros (FREIRE, 1992, p. 85-86).

A Terapia Comunitária é um espaço de compreensão da experiência humana e compreender o outro implica respeitar o outro. Ora, mas respeitar os saberes populares desse sujeito que vem para a Roda, significa claro, respeitar o contexto 
sócio-histórico, sua visão de mundo, suas crenças e valores, é em outras palavras, dar a esse sujeito o direito de ser sujeito. Também no movimento da PS, exercita-se a valorização dos diferentes saberes. Promover saúde é articular conhecimento e prática, é como dito anteriormente, a construção de uma visão transversal, múltipla, rica, includente, onde todos os saberes sejam valorizados, respeitados e utilizados. 


\section{A TERAPIA COMUNITÁRIA PROMOVENDO A SAÚDE - UM EXEMPLO}

O presente trabalho buscou estabelecer um diálogo entre a Terapia Comunitária e a Promoção da Saúde de maneira a identificar o grau de relação entre as duas e o quanto a Terapia Comunitária apresenta-se como ferramenta da Promoção da Saúde. Neste sentido, trazemos neste capítulo um recorte da atividade e os desdobramentos que ocorrem a partir dos encontros nas Rodas de Terapia Comunitária.

Como exemplo, citamos o projeto Paranoarte (Rede Solidária de Artesanato e Cultura Popular), que teve seu embrião a partir das Rodas de Terapia Comunitária que acontecia no Paranoá, cidade satélite distante $40 \mathrm{~km}$ de Brasília, oferecido pela organização não-governamental MISMEC - Movimento Integrado de Saúde Comunitária do Distrito Federal. Durante os encontros, assuntos como desemprego, falta de dinheiro, dificuldades financeiras e familiares eram recorrentes. Por tratar-se de uma comunidade carente do Distrito Federal, era comum que chegassem às rodas de terapia, senhoras depressivas, angustiadas e desesperançosas. Eram mulheres que já não saíam de casa, achavam-se incapazes e sofriam, silenciosamente. Ao participarem das rodas de Terapia Comunitária, tinham espaço para falarem de seus problemas e angústias, dividiam suas dores com outras mulheres igualmente amofinadas. Nessa troca, e a partir do olhar compreensivo e acolhedor dos membros do grupo e dos terapeutas comunitários, essas mulheres melhoravam, cresciam em esperanças e naturalmente iam surgindo idéias diferentes, possibilidades de enfrentamento diante daquele sofrimento. Idéias impensadas até então.

Como dissemos no decorrer do trabalho, a TC tem testemunhado o surgimento de processos individuais e coletivos de auto-soluções e inovações, uma vez que despreza o modelo salvador da pátria (aquele que gera dependência), e estimula nos seus participantes processos de crescimento e autonomia pessoal e comunitária. Foi isso que aconteceu, na prática, com as Rodas de TC que aconteciam no Paranoá.

Assim, depois de várias rodas de terapia, onde a cada encontro essas mulheres se sentiam mais e mais fortalecidas e crédulas de suas habilidades, surgiu a idéia e o consenso de que era indispensável que elas começassem a se sentir 
úteis. Uma das participantes dominava uma técnica de artesanato chamada amarradinho (técnica de amarração de restos de tecidos sobre uma base de algodão) e resolveu compartilhar com as demais, suas habilidades. Pouco tempo depois essas mulheres já começavam a vender suas 'obras de arte'. Estavam mais felizes e de acordo com o depoimento de algumas (ver site do Paranoarte), já começavam a se livrar dos remédios para dores, depressão e insônia.

Antes desempregadas e desassistidas, essas mulheres passaram para a condição de artesãs, com direito a carteirinha e esperança. Começavam a (re)construir sua cidadania, com ingredientes de coragem, arte e determinação. Se antes encontravam-se oprimidas e silenciadas, conseguiram, a partir dos encontros, despertar o potencial resiliente que se encontrava adormecido.

Essas mulheres fizeram coisas impensadas até pouco tempo atrás. Chegaram à roda de TC sofridas, adoecidas e sem perspectivas de futuro. Fortaleceram-se, uniram-se, começaram a fazer tapetes com a técnica do 'amarradinho', receberam consultoria do Sebrae, "desataram os nós" que a impediam de ver a capacidade resiliente e as habilidades individuais adormecida em cada uma. Criaram a coleção "Amarradinho em Você", participaram de feiras em São Paulo, viram seus produtos - roupas, bolsas, chapéus, bijuterias - nas passarelas de vários desfiles. Dos encontros da TC à inclusão social e geração de renda... esse foi o caminho percorrido.

Histórias com a da aposentada Sinira de Jesus, de 63 anos, que sustenta dois filhos, um dos quais com problemas mentais e de Corina de Souza que aos 48 ano viu-se desempregada e sem renda, são apenas dois dos inúmeros exemplos de 'empoderamento' e resiliência que podemos encontrar nas histórias nascidas a partir dos encontros nas rodas de terapia comunitária. Trouxemos do site do Paranoarte ${ }^{11}$ as seguintes reportagens:

A aposentada Sinira de Jesus é um exemplo [...] Aos 63 anos, ela sustenta um filho com problemas mentais e uma filha de 20 anos. "Sou de idade e não posso fazer nada. Aqui aprendo, ganho dinheiro e sou feliz", conta. Ela entrou no grupo a convite de uma amiga, como se fosse terapia para o reumatismo. Hoje, pretende levar a filha ao projeto para que ela possa ter a garantia de um futuro melhor.

\footnotetext{
${ }^{11}$ http://www.paranoarte.org/tribunadobrasil.htm. ACESSO: 15 de novembro de 2009
} 
Quando completou 48 anos de idade, Corina de Souza, então auxiliar de limpeza em uma firma particular, recebeu um presente de grego. A jovem senhora, às vésperas de comemorar cinco décadas de vida, viu a firma onde trabalhava fechar suas portas. Desempregada e sem renda, passou a se preocupar como faria para garantir o sustento dos sete membros da família. A idade avançada e os poucos anos de estudo tiraram as esperanças de Corina, que meses depois passou a freqüentar um grupo de terapia coletiva para comunidades carentes, oferecido pela organização não-governamental Movimento Integrado de Saúde Comunitária do Distrito Federal (Mismec-DF).

A Terapia Comunitária, por ser um espaço de interlocução dos sujeitos e um ambiente colaborativo, faz emergir o potencial resiliente dos participantes, bem como suas habilidades, muitas vezes adormecidas. Uma vez que está alicerçada na pedagogia de Paulo Freire, promove a autonomia e emancipação social do sujeito. O que ocorreu com os encontros de TC do Paranoá, foi a criação de redes sociais solidárias e espaço onde aquelas mulheres, enquanto atores sociais, tiveram a possibilidade de participar das discussões e decisões que envolviam suas próprias escolhas.

Neste exemplo, a TC atuou curativamente, uma vez que a partir das rodas muitas mulheres que estavam fazendo uso de medicação para insônia, depressão e dores receberam alta de seus médicos e também preventivamente, pois outras mulheres que não utilizavam medicação, mas que se encontravam 'no limite', possivelmente teriam mais cedo ou mais tarde necessidade de procurar os Postos de Saúde, caso não tivessem encontrado a 'cura' nas rodas de TC. É a Terapia Comunitária promovendo a saúde.

Lembramos que este trabalho não contou com entrevistas nem pesquisa qualitativa, desta forma todas as informações contidas neste capítulo foram trazidas dos sites do Mismec ${ }^{12}$ e do Paranoarte. Sugerimos, assim, que o leitor acesse os sites abaixo e leiam na íntegra as informações contidas aqui.

\footnotetext{
${ }^{12}$ http://www.mismecdf.org.
} 


\section{VIVÊNCIA - ENTENDENDO A RODA DE TERAPIA COMUNITÁRIA}

Para ficar claro como funcionam as Rodas de Terapia Comunitária, faremos agora um passo-a-passo, sobretudo para alcançar àqueles que ainda não tiveram o prazer de participar de uma delas.

As Rodas de TC acontecem, via de regra, uma vez por semana, a depender da disponibilidade dos terapeutas comunitários e da comunidade. Essas reuniões acontecem nos mais diferentes espaços - igrejas, templos, centros espíritas, escolas, órgãos públicos, centros de saúde, hospitais, bancos, centros/casas de cultura, centros comunitários e outros. As Rodas são facilitadas por pelo menos dois terapeutas (que chamamos de terapeuta e co-terapeuta). De acordo com Camargo (2005), metodologia que é utilizada nas Rodas é a que se segue ${ }^{13}$.

\section{1ำ passo: Acolhimento}

Neste momento o co-terapeuta deve dar as boas vindas aos participantes, de maneira acolhedora, para que os mesmo se sintam à vontade. O ideal é que estejam dispostos em círculo, para que todos possam se ver com facilidade. Em seguida acontece a celebração dos aniversariantes do mês - importante destacar que em algumas comunidades muito carentes, as pessoas se sentem valorizadas com esta lembrança, vez que acontece de aparecerem pessoas que nunca tiveram 'comemorados' seus aniversários. Depois, o co-terapeuta explica de forma clara, objetiva e sucinta o que é a TC: espaço privilegiado, de partilha, onde qualquer um pode colocar suas dores, alegrias, angústias e medos. Feito isso cita as regras da TC, quais sejam:

a) fazer silêncio: demonstrando respeito ao outro que fala;

b) falar sempre na 1aㅡ pessoa (EU): estimulando o sujeito a falar das suas próprias experiências;

c) não dar conselhos, não julgar, não fazer discurso ou sermão: já deixando subentendido a idéia de que ninguém sabe mais do que o outro;

\footnotetext{
${ }^{13}$ Nota da Autora: veja na íntegra a Dissertação de Mestrado em Psicologia de Amilton Carlos Camargo, no site da Abratecom - Associação Brasileira de Terapia Comunitária: http://www.abratecom.org.br/pdf/trabalhos_academicos/Dissertacao_Amilton.pdf
} 
d) propor músicas, histórias, provérbios que tenham a ver com o tema e que possam ajudar o sujeito que está falando, a refletir sobre sua história.

Também acontece nessa fase uma dinâmica de apresentação, de aquecimento. O ideal é que o co-terapeuta pergunte para o grupo se alguém lembra de uma brincadeira de criança, ou que Ihe traga boas recordações e caso alguém se disponha, pede para mostrar para o grupo. Caso contrário o próprio co-terapeuta sugere uma brincadeira. Isso é importante para deixar claro para os participantes que ali todos são 'iguais', não existe a idéia do 'doutor' que sabe mais que o outro. Terminando essa etapa com a dinâmica, o co-terapeuta passa a palavra ao terapeuta que dará continuidade aos trabalhos da Roda.

\section{2ำ passo: Escolha do Tema}

Composto por cinco procedimentos, o terapeuta pode começar estimulando o grupo a falar. Assim, pode citar dois ditados populares muito utilizados na Roda de TC: "quando a boca cala, os órgãos falam, quando a boca fala, os órgãos saram", ou "quem guarda, azeda, quando azeda estoura e quando estoura fede". Ao dizer isso, o terapeuta explica que quando a gente não fala dos nosso problemas, quando não temos como compartilhar nossas angústias, surge a insônia, a depressão e outros adoecimentos. O terapeuta também pode trazer uma fala de acolhimento que mostre aos participantes 0 ganho que ele pode ter ao expressar/compartilhar suas experiências.

Muitas vezes, precisamos desabafar, dividir uma preocupação e terminamos por escolher a pessoa errada, na hora errada, e aquele desabafo vira fofoca, e ficamos ainda mais sofridos e bloqueados. Portanto, se alguém quiser falar de algo que o atormenta, que tira seu sono. Você pode confiar nesta comunidade que, aqui, você não será julgado, e tenha certeza que irá receber ajuda e apoio de todos (CAMARGO, 2005, p. 39).

Mas também neste momento o terapeuta explica que na Roda não se deve falar segredos, uma vez que os segredos devem ser compartilhados apenas com pessoas da nossa absoluta confiança. Feito isso o terapeuta pergunta ao grupo quem gostaria de partilhar uma preocupação e pede para que a pessoa diga seu nome (que é anotado pelo terapeuta) e que em poucas palavras diga o que lhe aflige. Após cada fala o terapeuta deve 'restituir' uma síntese, como por exemplo: "deixe-me ver se entendi o que você falou. Caso não tenha entendido 
me corrija por favor". Isso é importante para que fique absolutamente claro qual a queixa do sujeito.

Ao final das falas, o terapeuta deve relembrar ao grupo o nome e a queixa de todos aqueles que se colocaram e pede que cada um diga com qual problema se identificou e o porquê, de maneira bem sucinta. Em seguida é feita a votação onde apenas um tema (situação problema) é escolhido, para ser aprofundado. Terminada a votação, o terapeuta pergunta aos outros participantes que também colocaram seus problemas se está tudo bem, mesmo não tendo sido escolhido o tema. Caso o terapeuta perceba que alguém ficou triste ou aborrecido por não ter seu tema escolhido, lembra ao sujeito que ele poderá voltar na outra semana e recolocar seu tema. Além disso, o terapeuta se prontifica a conversar com essa pessoa ao final da Roda. Agradece a todos que externaram suas dores, e passa para a próxima etapa.

\section{3ำ passo: Contextualização}

Neste momento o terapeuta pede para o sujeito que teve sua 'situação problema' escolhida, discorrer mais detalhadamente sobre o assunto. Durante a explanação, os participantes da Roda podem fazer perguntas para a pessoa, sempre com o objetivo de esclarecer/entender o assunto, e não para satisfazer as curiosidades individuais. Além disso, o terapeuta esclarece que o sujeito só responderá as perguntas que quiser, quando se sentir a vontade para fazê-lo (o terapeuta, no início deste passo, deixa isso bem claro). É isso que o terapeuta faz e pede para que o grupo faça: perguntas! O sujeito vai responder, e respondendo, ele toma consciência de si mesmo, do outro, do contexto. Quanto mais respostas o sujeito dá, mais consciência ele passa a ter.

Depois que o sujeito cujo tema foi escolhido falou detalhadamente sobre seu sofrimento e respondeu a todas as perguntas, o terapeuta agradece e pede para que ele fique em silêncio e ouça os outros membros.

O objetivo desta etapa é fazer com que a pessoa que trouxe a situação problema fale sobre ele, trazendo lembranças as vezes adormecidas, que possa fazer uma reflexão sobre sua história, como ela tem se colocado diante dos acontecimentos, o que tem ganhado e o que tem perdido com a situação vivida e com o comportamento escolhido. 


\section{4ำ passo: Problematização}

Neste momento o terapeuta lança o mote, ou seja, uma pergunta-chave que busque identificar/definir a situação problema. $O$ terapeuta pode utilizar-se de uma metáfora, por exemplo, para fazer com que os outros participantes lembrem-se de suas próprias experiências. Lembramos que o terapeuta comunitário é um 'despertador de lembranças' e pode com suas perguntas e reflexões, ajudar o sujeito a acessar as próprias lembranças. Também pode lançar um mote coringa: "quem já viveu uma situação parecida e o que fez para resolvê-la ou aprender a conviver melhor com ela? Os que quiserem partilham suas experiências. Depois de ouvir com atenção a todos, o terapeuta agradece a participação e passa para a próxima etapa.

50 passo: Encerramento - rituais de agregação e conotação positiva

Trata-se de uma fase muito importante. O terapeuta devolve a palavra ao co-terapeuta que pede para que todos fiquem de pé, fazendo uma roda. Nesse momento é importante agradecer o esforço e a coragem de todos que fizeram parte da Roda, sobretudo daqueles que se colocaram. O terapeuta ou coterapeuta pode, ao agradecer, citar os nomes das pessoas que falaram: "eu quero agradecer a x, y, z (fala o nome de cada um), por confiarem no grupo, por nos enriquecerem com suas experiências tão significativas...", e nesse momento ressalta o valor de cada um, o aspecto positivo de cada pessoa que falou: "Maria, você é um exemplo de mulher forte, corajosa, já passou por tantos problemas e continua acreditando na vida... você é um exemplo para todos nós, homens e mulheres...". Ao fazer isso o terapeuta está tentando mostrar para o sujeito o potencial resiliente que ele tem, e também estimula os outros componentes do grupo a fazerem o mesmo. Importante lembrar que não há a valorização, mas sim o respeito ao sofrimento; o que buscamos neste momento é exatamente isso: reconhecer o esforço para a superação do sofrimento. Em seguida pede-se para cada um dizer o que está levando desta partilha tão rica de experiências. Nesta etapa propõe-se músicas, provérbios, poesias. E assim, chega-se ao fim de mais uma Roda, momento em que os terapeutas convidam os participantes a virem no próximo encontro. 


\section{6o passo: Apreciação}

Neste momento a equipe reflete sobre seu trabalho. É quando os terapeutas se encontram sozinhos e fazem uma avaliação da Roda. O que foi bom? o que pode melhorar? Assim, olham para a experiência da Roda com o objetivo de abrir novas possibilidades e caminhos futuros.

Os terapeutas preenchem uma ficha: Apreciação da Atuação da Equipe de Terapeutas Comunitários, que se refere à reflexão da equipe sobre o desenvolvimento da terapia nas suas diferentes etapas: acolhimento, escolha do tema, contextualização, problematizarão e encerramento. 


\section{CONSIDERAÇÕES FINAIS}

Quando pensamos num estudo que promovesse o diálogo entre Terapia Comunitária e Promoção da Saúde, não tínhamos a real dimensão de como esses dois movimentos se harmonizam. Falar sobre a confluência entre PS e TC é importante porque esses movimentos vêm crescendo muito nos últimos anos. Um nasceu no Ceará, nordeste brasileiro, e hoje se encontra com pólos formadores em várias cidades da Europa. O outro nasceu na Europa, e hoje se encontra em todo o mundo, inclusive com muita força no Brasil, aonde vem influenciando sobremaneira políticas públicas nos mais diversos espaços.

A partir do que foi discutido até aqui, podemos dizer que Saúde é um processo dinâmico que abrange múltiplas configurações; envolvendo aspectos sócio-históricos, culturais, emocionais, econômicos, políticos e pessoais, entre outros. É a capacidade/possibilidade do sujeito de Criar, Realizar e Amar. Trata-se de processo também subjetivo, do ponto de vista de ser o sujeito produtor de uma história pessoal que se constrói a partir das suas relações sociais, e vice-versa. Negar esses aspectos sociais e individuais que se retroalimentam, é negar o próprio sujeito.

Acreditamos agora, que só existe um caminho para se chegar à Promoção da Saúde: a cidadania. Depois de todos os textos lidos, sem dúvida o passo que escolhemos é o que leva ao fortalecimento da comunidade, do resgate da sua cidadania e isso é possível a partir do 'encontro' que o sujeito estabelece com o outro. Lembramos da "ação libertadora" de Paulo Freire: "a liberdade dos oprimidos é libertação de homens e não de coisas". Portanto, se não é autolibertação, também não é libertação de uns, feita por outros. Para Freire "ninguém liberta ninguém, ninguém se liberta sozinho: os homens se libertam em comunhão" (FREIRE, 2005, p. 52).

O primeiro passo que deve ser dado é permitir que a comunidade se fortaleça. É acreditar que a partir da autonomia e sentimento de responsabilidade e pertencimento, os grupos organizados são capazes de realizar uma verdadeira revolução social, promovendo a construção de uma sociedade mais justa e solidária, consciente dos seus deveres perante os outros, perante si mesma e perante o meio ambiente. $O$ resto virá por acréscimo. Uma comunidade atuante, consciente, esclarecida e politizada cobrará dos seus governantes uma postura 
mais respeitosa e responsável; refletirá sobre a questão do consumo, das necessidades reais e ilusórias.

Saímos de um modelo puramente positivista e buscamos encontrar uma nova visão/compreensão de saúde-doença-cuidado. Estamos em busca de uma visão mais abrangente e inclusiva, que tem tudo a ver com essa nova 'noção de sujeito'. Se na década de 40 a definição de saúde como 'estado de completo bem estar físico, mental e social' era suficiente, hoje buscamos muito mais. Procuramos entender - para melhor enfrentar - os determinantes sociais da saúde, compreendendo que a mudança de paradigma é condição primeira para estabelecermos um diálogo intersetorial, mobilização social e políticas públicas para efetivamente Promovermos a Saúde.

Estamos lutando pelo enfraquecimento do modelo biomédico, medicalizante, reducionista e curativo e buscando um modelo transformador, capaz de acolher a idéia da multi/transdisciplinaridade. Um modelo abrangente, que entenda a saúde como um processo que alia valores como: democracia, solidariedade, responsabilidade, vida, saúde, cidadania, equidade e participação. A visão míope do processo saúde-doença ainda traz grandes atrasos: os crescentes investimentos na assistência curativa e individual em detrimento do bem-estar humano, possível por meio do fortalecimento dos atores sociais, ou seja, do empoderamento das comunidades; das redes sociais solidárias; da escolarização; da cultura.

Sem dúvida, as condições de vida e saúde têm melhorado, inclusive nos países mais pobres. Na época da II Guerra Mundial a expectativa de vida na América Latina era de 50 anos, na década de 90 subiu para 69 anos. Entretanto, as profundas desigualdades sociais permanecem e trazem consigo perversos efeitos. (MAIA.2008).

Veio Alma-Ata, veio a Carta de Ottawa, Bogotá, Conferência do Caribe, Declaração de Adelaide, Sundsvall e Jacarta. Muita coisa evoluiu - pelo menos no campo teórico. Mas ainda há muito que ser resgatado. Como disse Marcondes (2004), é necessária a ação efetiva e coordenada dos atores sociais para a consolidação da promoção da saúde. Pensar em Promoção de Saúde, tirar do papel e do campo das idéias toda teoria produzida desde 1978 e mesmo antes disso, e exemplificar por meio de ações efetivas a Promoção da Saúde, é necessário. Para tanto deve-se observar vários aspectos: fortalecimento das 
comunidades, dando-lhe espaço para atuar e discutir; eliminação ou redução das desigualdades sociais; efetivo diálogo entre os diversos setores da sociedade; desenvolvimento de políticas públicas saudáveis e a questão urgente da proteção aos recursos naturais.

Ações que funcionem como fomentadoras da construção ou resgate da cidadania, das tão enriquecedoras redes sociais solidárias capazes de resgatar a auto-estima dos sujeitos - atuação tão exemplar da Terapia Comunitária - e políticas públicas bem fundamentadas, são o caminho para a construção da Promoção da Saúde. Sem isso, continuaremos nesse 'diálogo' inócuo e atrasado.

Desta forma a Terapia Comunitária tem se consolidado como estratégia de Promoção da Saúde, uma vez que compartilham diversos princípios, como por exemplo: a pedagogia de Paulo Freire - autonomia do sujeito, educação como prática libertadora, educação significativa - a horizontalidade dos saberes, a emancipação social, a educação permanente em saúde.

Refletir sobre os 'nós' que são construídos e que favorecem a ineficácia do incremento da saúde é há tempos pontuada por muitos profissionais, entre eles, os que detêm experiências em projetos sociais, que vêm mostrando a necessidade de valorização dos atores sociais. A valorização dos líderes comunitários é ponto fundamental para a construção da Promoção da Saúde. Via de regra, esses atores sociais (como os líderes comunitários) são marginalizados, entre outros fatores, pela necessidade que os 'especialistas' têm em mostrar seus saberes. A hierarquização do saber ainda é muito gritante e esta divisão entre os que sabem e estão 'para ajudar e ensinar' e os que 'nada sabem', embaraça a interlocução dos atores sociais.

Os espaços de participação criados espontaneamente são absolutamente legítimos, pois expressam a essência da comunidade, suas aspirações, sonhos, desejos. A partir destes ambientes colaborativos, são criadas as redes sociais, espaços onde os atores sociais têm oportunidade de participar ativamente das discussões e decisões.

Ao trazermos uma síntese dos pilares teóricos da Terapia Comunitária, automaticamente contemplamos os referenciais teóricos da Promoção da Saúde. É interessante perceber o quanto esses pilares são complementares. A pedagogia de Paulo Freire, que reforça a autonomia do sujeito, ao insistir numa 
educação libertadora, o potencial resiliente do sujeito que o faz participar das Rodas, que o faz acreditar que é possível, mas também, em outros casos, a TC que contribui no sentido de despertar em determinado sujeito o potencial resiliente que ele tem, e muitas vezes nem sabe que tem. Na Roda ele é estimulado a 'acessar' essas habilidades adormecidas e esquecidas!

Assim, o desejo que nos move, é que os profissionais de saúde utilizemse destes saberes construídos espontaneamente e repensem suas práticas profissionais, sua visão de mundo e que adiram para esse novo paradigma de Promoção da Saúde. 


\section{REFERÊNCIA BIBLIOGRÁFICA}

1. ALVES, Elioenai Dornelles; SAUPE, Rosita. Contribuição à construção de projetos político-pedagógicos na enfermagem. Rev.latino am. enfermagem, Ribeirão Preto, v. 8, n. 2, p. 60-67, abril 2000.

2. ALVES, Elioenai Dornelles; POLONIA, Ana da Costa. Ações Educativas em Saúde: Repensando Paradigmas. Brasília, 2003

3. BARRETO, Adalberto de Paula. Terapia Comunitária passo a passo. Gráfica LCR, $3^{a}$ ed. Revista e ampliada, Fortaleza, 2008

4. BOFF, Leonardo. Saber Cuidar: ética do humano - compaixão pela terra. Editora Vozes, Petrópolis, Rio de Janeiro: 1999

5. BUSS, Paulo Marchiori. Promoção da Saúde e Qualidade de Vida. Ciência \& Saúde Coletiva vol. 5, no 1, Rio de Janeiro, 2000

6. BUSS, Paulo Marchiori. Uma Introdução ao Conceito de Promoção de Saúde. In: CZERESNIA, d.; FREITAS, C.M. (Org.). Promoção da Saúde: conceitos, reflexões, tendências. Ed. FIOCRUZ, Rio de Janeiro, 2003, p. 15-38

7. CAMARGO, Amilton Carlos. Tempo de falar e tempo de escutar: a produção de sentido em um grupo terapêutico. Universidade de São Marcos, 2005. dissertação de Mestrado em Psicologia. Acesso em 1 de novembro de 2009. < www.abratecom.org.br/pdf/trabalhos_academicos/Dissertacao_Amilton.pdf>

8. CANADÁ. Carta de Ottawa. Primeira Conferência Internacional sobre Promoção Da Saúde. Ottawa, nov. 1986. Acesso em 27 de set. 2009. < www.opas.org.br/coletiva/uploadarq/ottawa.pdf>.

9. CARVALHO, Sérgio Resende. Os Múltiplos Sentidos da Categoria "Empowerment" no Projeto de Promoção à Saúde. Cad. Saúde Pública, 20(4): 101088-1095, jul-ago, 2004. Acesso em 10 de outubro de 2009. <www. epsjv.fiocruz.br/upload/d/Os_multiplos_sentidos_da_categoria_empowerment_no_pr ojeto_da_promocao_da_saude.pdf>

10. CARVALHO, Antônio Ivo de. Conselhos de Saúde no Brasil/ Antônio Ivo de Carvalho_ Rio de Janeiro: FASE/IBAM, 1995. 136 p. Dissertação e mestrado defendida na Escola Nacional de Saúde Pública, Fundação Oswaldo Cruz no ano de 1994.

11. CECCIM, Ricardo Burg. Educação Permanente em Saúde: descentralização e disseminação de capacidade pedagógica na saúde. Ciência \& Saúde Coletiva. 
v..10, n.4, pp. 975-986. Rio de Janeiro. Oct/Dec.2005. Acesso em 06 de out. 2009. <www.scielosp.org/scielo.php?pid=s1413-81232005000400020\&script=sci.arttext>

12. CECCIM, Ricardo Burg. Educação Permanente em Saúde: desafio ambicioso e necessário. Revista Inteface - Comunic, Saúde, Educ, v. 9, n. 16, p. 161-77, set. 2004/fev. 2005.

11. FERLA, Alcindo Antônio. Participação da População: do Controle sobre os Recursos a uma Produção Estética da Clínica e da Gestão em Saúde. PHYSIS: Rev. Saúde Coletiva, Rio de Janeiro, 14(1): 85-108, 2004.

13. FLEURI, Reinaldo Matias. Ensinar e aprender: sujeitos, saberes e pesquisa. Encontro Nacional de Didática e Prática de Ensino (ENDIPE) - Rio de Janeiro: DP\&A, 2002. 2ª edição.

14. FREIRE, Paulo. Pedagogia do Oprimido. Rio de Janeiro, Paz e Terra, 2005.

15. FREIRE, Paulo. Pedagogia da Esperança: um reencontro com a Pedagogia do Oprimido. Rio de Janeiro: Paz e Terra, 1992.

16. FREIRE Paulo. Pedagogia da autonomia: saberes necessários à prática educativa. São Paulo: Paz e Terra, 1996.

17. FREITAS, Ana Lúcia Souza de. Pedagogia da Conscientização: um legado de Paulo Freire à formação de professores. Porto Alegre: EDIPUCRS, 2004.

18. GIMENEZ, Maria da Glória G. A Mulher e o Câncer. Campinas: Editora Psy Ltda, 1997.

19. GODOY, Marília, G. Ghizzi. Os Desafios da Antropologia em favor da interdisciplinaridade. Revista Tempo \& Memória. Ano 2. № 2. janeiro-julho 2004. Atropologia. p. 21-32. Acesso em: 16 de set 2009. $<$ www.culturaesociedade.org/pdf/introduantropologia2.pdf>

20. GONZÁLEZ REY, Fernando Luis. Sujeito e Subjetividade: uma aproximação histórico-cultural. São Paulo: Thomson Learning. 2003.

21. GOHN, Maria da Glória. Teorias dos movimentos sociais - Paradigmas clássicos e contemporâneos. São Paulo: Edições Loyola, 2002.

22. JOVCHELOVITCH, Sandra; GUARESCHI, Pedrinho. (orgs). Textos em Representações Sociais. Petrópolis, Rio de Janeiro: Vozes, 2002.

23. KOWALSKI, Ivonte S. G. e SOUSA, Clarilza P. Câncer: uma doença com representações historicamente construídas. Revista Acta Oncológica, v. 22, no 4. 2002. 
24. LEFEVRE, Fernando. O Sujeito da Promoção da Saúde. FPS/USP 1999. Acesso em: 24 de ago 2009. <www.projetoradix.com.br/arq_artigo/cs/III_9.pdf>

25. MAIA, Luiz Faustino Santos. Qualidade de vida se faz com promoção e educação da saúde. Enfermagem. São Paulo, outubro de 2008. Acesso em 17 de mai de 2009. < www.webartigos.com>

26. MATTERLARD, Armand \& Michele. História das teorias da comunicação. São Paulo, Loyola, 1999.

27. NOVOA, Carlos Alberto Torres. Leitura crítica de Paulo Freire. São Paulo: Edições Loyola - tradução de Mônica Mattar Oliva. 1981.

28. OLINDA, Querubina Bringel; SILVA, Carlos Antônio Bruno da. Retrospectiva do Discurso sobre Promoção da Saúde e as Políticas Sociais. Revista Brasileira em Promoção da Saúde. Volume 20 número 2. 2007 Unifor Fortaleza. RBPS 2007; 20 (2): 65-67 67

29. OPAS - Declaração de Santafé de Bogotá: Conferência Internacional de Promoção da Saúde. Santafé de Bogotá, Colômbia, 9-12 de novembro de 1992. Acesso em 28 de ago de 2009. <www.opas.org.br/coletiva/uploadArq/Santafe.pdf>

30. RAMISTHALER, Anna Luiza. A ARTE DE SE RELACIONAR: Impulsionando a produtividade. Brasília. Ed. Conhecimento. 2006.

31. RIVERO. David A. Tejada de. Alma-Ata, 25 años después. Revista Perspectivas de Salud. La revista de la Organización Panamericana de la Salud. OPS. v. 8, n. 2, p. 1-3, 2003. Acesso em 14 de ago 2009. <www.paho.org/Spanish/dd/pin/numero17_articulo_1_1,htm>

32. ROCHA, S.M.M.; ALMEIDA, M.C.P.de. O processo de trabalho da enfermagem em saúde coletiva e a interdisciplinaridade. Rev.latino-am.enfermagem, Ribeirão Preto, v. 8, n. 6, p. 96-101, dezembro 2000. Acesso em 17 de out 2009. $<$ www.scielo.br/pdf/rlae/v.8n6/12354.pdf>

33. Rodrigues e Santos - Empowerment: Estudo de Casos em Empresas Manufatureiras. G\&P: Gestão e Produção. v.11, n.2, p. 263-274, mai.-ago. 2004. $<$ www.scielo.br/pdf/gov/v11n2/a12v11n2.pdf>

34. ROSCHKE, Maria Alice (In: III - EDUCAÇÃO PERMANTENTE EM SAÚDE COMO NOÇÃO ESTRATÉGICA NA FORMAÇÃO E DESENVOLVIMENTO PARA O SUS. Secretaria de Gestão do Trabalho e da Educação na Saúde. Departamento de Gestão e da Educação na Saúde. Brasília 2003. Acesso em 30 de set 2009. $<$ www.saude.gov.br>

35. SAVATER, Fernando. Política para meu filho. São Paulo: Editora Martins Fontes, 2001.

36. SEGRE, Marco; FERRAZ, Flávio Carvalho. O Conceito de Saúde (1997). São Paulo, Revista de Saúde Pública - Journal of Public Health. 
37. SPOSATI, Aldaíza; LOBO, Elza. Controle Social e Políticas de Saúde. Cad. Saúde Públ., Rio de Janeiro, 8 (4): 366-378, out/dez, 1992.

38. TEIXEIRA. Carmen Fontes. Formulação e implementação de políticas públicas saudáveis: desafios para o planejamento e gestão das ações de promoção de saúde nas cidades. Saúde soc. [online]. 2004, vol. 13, n.1, pp. 37-46. Acessado em 1 de out. 2009. <www.scielo.br/scielo.php?script=sci_arttext\&pid>

39. WALSH, Froma. Resiliencia familiar: Estratégias para su fortalecimiento. Buenos Aires: Amorrortu. 2004. 